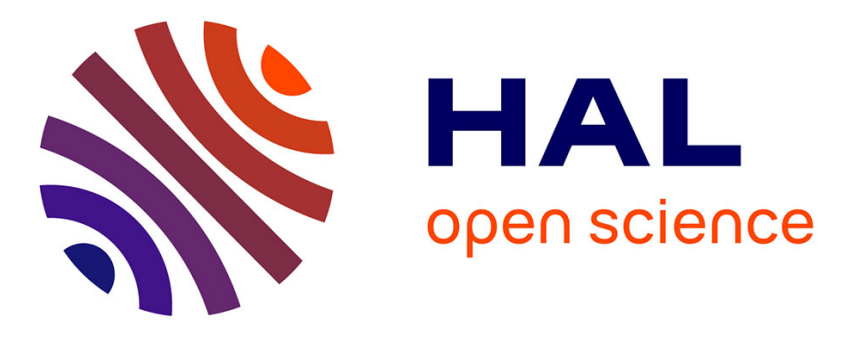

\title{
Search for the genes involved in oocyte maturation and early embryo development in the hen
}

Sébastien Elis, Florence Batellier, Isabelle Couty, Sandrine Balzergue,

Marie-Laure Martin-Magniette, Philippe Monget, Elisabeth Blesbois, Marina

Govoroun

\section{To cite this version:}

Sébastien Elis, Florence Batellier, Isabelle Couty, Sandrine Balzergue, Marie-Laure Martin-Magniette, et al.. Search for the genes involved in oocyte maturation and early embryo development in the hen. BMC Genomics, 2008, 9, pp.1-20. 10.1186/1471-2164-9-110 . hal-02666483

\section{HAL Id: hal-02666483 \\ https://hal.inrae.fr/hal-02666483}

Submitted on 31 May 2020

HAL is a multi-disciplinary open access archive for the deposit and dissemination of scientific research documents, whether they are published or not. The documents may come from teaching and research institutions in France or abroad, or from public or private research centers.
L'archive ouverte pluridisciplinaire HAL, est destinée au dépôt et à la diffusion de documents scientifiques de niveau recherche, publiés ou non, émanant des établissements d'enseignement et de recherche français ou étrangers, des laboratoires publics ou privés. 


\title{
Search for the genes involved in oocyte maturation and early embryo development in the hen Sebastien Elis ${ }^{1}$, Florence Batellier ${ }^{1}$, Isabelle Couty ${ }^{1}$, Sandrine Balzergue ${ }^{2}$, Marie-Laure Martin-Magniette ${ }^{2}$, Philippe Monget ${ }^{1}$, Elisabeth Blesbois ${ }^{1}$ and Marina S Govoroun*1
}

Address: ${ }^{1}$ Physiologie de la Reproduction et des Comportements, UMR 6175 INRA-CNRS-Université F. Rabelais de Tours, Haras Nationaux, 37380 Nouzilly, France and '2Unité de Recherche en Génomique Végétale UMR INRA 1165 - CNRS 8114 - UEVE 2 Rue Gaston Crémieux, CP 570891057 Every cedex, France

Email: Sebastien Elis - sebastien.elis@voila.fr; Florence Batellier - florence.batellier@tours.inra.fr; Isabelle Couty - isabelle.couty@tours.inra.fr; Sandrine Balzergue - balzerg@evry.inra.fr; Marie-Laure Martin-Magniette - martin@evry.inra.fr;

Philippe Monget - philippe.monget@tours.inra.fr; Elisabeth Blesbois - elisabeth.blesbois@tours.inra.fr; Marina S Govoroun* - marina.govoroun@tours.inra.fr

* Corresponding author

Published: 29 February 2008

BMC Genomics 2008, 9:110 doi:10.1/86/147|-2164-9-110
Received: 12 September 2007

Accepted: 29 February 2008

This article is available from: http://www.biomedcentral.com/147I-2164/9/110

(C) 2008 Elis et al; licensee BioMed Central Ltd.

This is an Open Access article distributed under the terms of the Creative Commons Attribution License (http://creativecommons.org/licenses/by/2.0), which permits unrestricted use, distribution, and reproduction in any medium, provided the original work is properly cited.

\begin{abstract}
Background: The initial stages of development depend on mRNA and proteins accumulated in the oocyte, and during these stages, certain genes are essential for fertilization, first cleavage and embryonic genome activation. The aim of this study was first to search for avian oocyte-specific genes using an in silico and a microarray approaches, then to investigate the temporal and spatial dynamics of the expression of some of these genes during follicular maturation and early embryogenesis.

Results: The in silico approach allowed us to identify 18 chicken homologs of mouse potential oocyte genes found by digital differential display. Using the chicken Affymetrix microarray, we identified $46 \mathrm{I}$ genes overexpressed in granulosa cells (GCs) and 250 genes overexpressed in the germinal disc (GD) of the hen oocyte. Six genes were identified using both in silico and microarray approaches. Based on GO annotations, GC and GD genes were differentially involved in biological processes, reflecting different physiological destinations of these two cell layers. Finally we studied the spatial and temporal dynamics of the expression of $2 \mathrm{I}$ chicken genes. According to their expression patterns all these genes are involved in different stages of final follicular maturation and/or early embryogenesis in the chicken. Among them, 8 genes (btg4, chkmos, wee, zpA, dazL, cvh, zarl and ktfn) were preferentially expressed in the maturing occyte and cvh, zarl and $k t f n$ were also highly expressed in the early embryo.

Conclusion: We showed that in silico and Affymetrix microarray approaches were relevant and complementary in order to find new avian genes potentially involved in oocyte maturation and/or early embryo development, and allowed the discovery of new potential chicken mature oocyte and chicken granulosa cell markers for future studies. Moreover, detailed study of the expression of some of these genes revealed promising candidates for maternal effect genes in the chicken. Finally, the finding concerning the different state of rRNA compared to that of mRNA during the postovulatory period shed light on some mechanisms through which oocyte to embryo transition occurs in the hen.
\end{abstract}




\section{Background}

The activation of molecular pathways underlying oocyte to embryo transition (OET) depends exclusively on maternal RNAs and proteins accumulated during growth of the oocyte [1]. During OET and preimplantation development in mice, the embryo becomes almost autonomous, and may gradually eliminate maternal components. Indeed, by the two cell stage, the major pathways regulated by maternal mRNA are targeted protein degradation, translational control and chromatin remodelling [2]. The recruitment of maternal mRNA for translation has long been recognized as a widespread mechanism to generate newly synthesized proteins in maturing oocytes and fertilized eggs [3]. Conversely, RNA that is no longer needed is actively degraded in the early embryo [4]. Moreover, careful regulation of proteolysis during the same period is likely to be important in oocytes, which are predominantly transcriptionally inactive and must often wait for long periods before fertilization in different species such as Drosophila, Xenopus, Caenorhabditis and Zebrafish [5]. Maternal transcripts that are present in the early preimplantation embryo can be subdivided into two classes according to whether they are re-synthesized soon after embryonic genome activation or not. The first is common to the oocyte and early embryo and is replenished after activation of the zygotic genome. The second consists of oocyte-specific mRNA that is not subsequently transcribed from zygotic genes in the embryo. This class of mRNA may be detrimental to early post-fertilization development [6].

Maternal effect genes have been found in several species ranging from invertebrates to mammals. Wide screening of mutants has been performed in invertebrates as Drosophila melanogaster [7] and Caenorhabditis elegans [8] where several mutations lead to arrest of early embryo development. Although females bearing this type of mutation are viable and appear to be normal, the development and survival of their embryos are compromised [9]. Maternal effect mutations have also been described in other vertebrates such as Danio rerio for the nebel gene [10], and Xenopus laevis for the af gene [11]. Despite the fact that maternal effect mutations are well known in lower organisms, only a few examples have been reported in mammals. All of them are based on knock-out experiments and concern three murine genes, i.e. Dnmt1, Hsf1 and Mater [9]. Mater (Maternal antigen that embryos require) is a single-copy gene that is transcribed in growing oocytes. Although its transcripts are degraded during meiotic maturation, MATER protein persists into the blastocyst. Female mice lacking this $125 \mathrm{kDa}$ cytoplasmic protein produce no offspring because of an embryonic block at the early cleavage stage. Thus, Mater is one of few documented genes for maternal effect in mammalian development [12]. Mater has been found in bovine models but there is no report in the literature on maternal effect genes conserved between species.

No information has been available to date on maternal effect genes in birds. However, birds represent a good model to observe progressive accumulation of mRNA in the oocyte before ovulation. The embryonic genome of a model bird, i.e. the chicken, is activated when the embryo contains 30,000-50,000 cells [13] $24 \mathrm{~h}$ after fertilization. Proteins and mRNA, accumulated as the chicken oocyte matures, are essential not only for fertilization and first cleavage but also for supporting a high number of embryonic cell divisions before genome activation. By comparison, the embryonic genome is activated at the 8-cell stage in bovines [14] and at the 2-cell stage in the mouse [15]. The avian oocyte consists of a large amount of yolk and a structure called the germinal disc (GD) [16]. The GD is a white plaque of about 3-4 mm diameter on the top of the oocyte. It contains the nucleus and $99 \%$ of oocyte organelles although it occupies less than $1 \%$ of the cell volume [17]. Structurally, and therefore functionally, the GD is mostly equivalent to the mammalian oocyte. The ovary of the reproductively active hen consists of small pre-hierarchical follicles and maturing preovulatory follicles showing a hierarchy according to size (F6 to F1) [18].

Only a few studies have reported on gene expression in the oocyte and during early embryo development in the chicken. The dynamics of the overall RNA profile of the chicken oocyte through different maturation stages has been described by Olzanska et al. [13,19-22]. Chicken vasa homolog protein $(\mathrm{CVH})$ was hypothesized to be maternally inherited in the chicken embryo, since it has been localized in chicken oocytes and during first cleavage [23]. Another protein, Epidermal Growth Factor, was found in F2 GD and its potential role in follicular development has also been investigated [24].

Since oocyte-specific genes expressed during follicular maturation and after ovulation are potentially involved in the fertilization process and in early embryo development, and almost no information is available on these genes in birds, the aim of this study was to identify avian oocyte-specific genes and then to investigate the temporal and spatial dynamics of their expression during follicular maturation and early embryogenesis. We chose initially to focus on oocyte-specific genes because the accumulation of their transcripts in the oocyte should have greater consequences on fertilization and OET. Two different strategies were used to identify avian genes potentially involved in oocyte developmental competence. The first was based on a candidate gene approach and consisted of a search for avian homologs of murine oocyte genes, previously identified by digital differential display [25]. The second strategy involved a global transcriptomic approach based 
on chicken Affymetrix microarray. We report here several novel chicken genes with potential maternal effect identified using these two strategies. We also describe the spatial and temporal dynamics of the expression of some of these genes as well as some potential mechanisms in which they could be involved. We also compare chicken and murine orthologs in terms of their tissue specificity and their potential involvement in oocyte developmental competence and/or early embryogenesis.

\section{Results \\ In silico search for chicken homologs of murine oocyte genes}

Differential digital display analysis performed on murine tissues provided a list of 101 potentially oocyte-specific murine genes [25-27]. Bioinformatic analyses were performed on this list of genes in order to find potentially oocyte-specific chicken orthologs. Genes with a blast score higher than 100 were localized using mapview [28] and blatsearch [29] tools. The syntenic regions were checked: chromosome localization of murine genes and chicken homologs were compared, in order to obtain the correct chicken ortholog of mice genes. Only genes with sufficient homology or whose localization was in accordance with syntenic regions were selected. Forty-one chicken genes were eliminated because of their poor homology with murine genes and 32 other genes were eliminated because they were localized outside the syntenic regions. Among the remaining 28 chicken genes the transcript of only 18 genes could be correctly amplified using real time or classic RT-PCR, of which the detailed study of two genes bmp15 and $g d f 9$ has previously been reported [30]. Thus 16 avian genes were finally retained (Table 1 ). The homology with murine genes was strong for 11 of these genes (blast score between 288 and 2149) and was weak for 5 (blast score between 104 and 132). The last five chicken genes were nevertheless considered as potential orthologs of murine genes and kept as candidate genes because of their correct localizations with respect to the syntenic region. Eleven of the selected genes were localized in the expected syntenic region (btg4, chkmos, msh4, mtprd, mcmip, znfingerRIZ, discs5, trans fact 20, wee, zar1 and ktfn). Three other genes were localized in the vicinity of the expected syntenic region ( $d a z L$, fbox and mark3). Two genes were localized in the unexpected syntenic region, but they were identified with the same name as murine genes $(z p A$ and $z p C)$.

\section{Comparing oocyte and granulosa cells transcription profiles at final maturation steps using chicken Affymetrix microarrays}

The samples studied were: F1 GCs, corresponding to granulosa cells (GCs) of the largest follicles before ovulation (F1); F1 GDR, corresponding to the germinal disc region (GDR) of F1 follicles, and Ov GDR, corresponding to the germinal disc region of ovulated oocytes (Ov) (Fig. 1). Apart from the stage of maturation the main difference between these samples involved the presence of granulosa cells. They were not present in GDR from ovulated oocytes, they were slightly present in F1 GDR, and they constituted a major component of F1 GCs (see Materials and Methods). Statistical analysis of data obtained after Affymetrix microarray hybridization provided lists of genes differentially expressed in three comparisons: F1 GDR and Ov GDR, F1 GDR and F1 GCs, and Ov GDR and F1 GCs (accession number GSE7805). There were only a few differentially expressed genes in each comparison (fewer than 500 out of 28000 genes on the Chip) (Table 2). Indeed, the first comparison, between the F1 GDR and Ov GDR, showed 92 genes over-expressed at the F1 stage, including one of our in silico identified genes $(z p C)$. In the second comparison, between F1 GDR and F1 GCs, 342 differentially expressed genes were identified. These genes involved 104 genes over-expressed in F1 GCs and 238 genes over-expressed in F1 GDR. Five of our in silico identified genes btg4, chkmos, dazL, zpA and ktfn were found among the latter genes over-expressed in F1 GDR (Table 2 ). The third analysis compared the expression of genes between F1 GCs and Ov GDR. We obtained a set of 448 genes that were differentially expressed between F1 GCs and Ov GDR, of which 392 genes were over-expressed in F1 GCs and 56 genes were over-expressed in Ov GDR. We found 1 of our in silico identified genes among these genes, (btg4) (Table 2). The Venn diagram (Fig. 2) shows overlapping differentially expressed genes between different dataset comparisons. Eighty-five differentially expressed genes were common for two comparisons (F1 GCs and Ov GDR, and F1 GCs and F1 GDR). Only one gene was common for the comparisons between F1 GDR and F1 GCs, and F1 GDR and Ov GDR and 1 gene was common for all three comparisons. F1 GDR samples contained a quantity of granulosa cells in contrast to Ov GDR samples which were free of granulosa cells. Analysis of the redundancy of over-expressed genes between different comparisons was therefore performed in order to distinguish between genes found over-expressed in F1 GDR samples due to granulosa cell contamination and those really over-expressed in the oocyte (Fig. 3). This analysis revealed that 85 of 92 genes over-expressed in F1 GDR were also over-expressed in F1 GCs, both compared to Ov GDR, indicating that these genes characterized granulosa cell expression rather than variation in the expression between F1 GD and Ov GD. Thus only 7 genes should be considered as overexpressed in F1 GD compared to Ov GD. Moreover, of the 104 genes overexpressed in F1 GCs compared to F1 GDR, 36 were also overexpressed in F1 GCs compared to Ov GDR. Consequently, taking into account the latter redundancy, a total of 460 genes was overexpressed in granulosa cells compared to oocytes. On the other hand 49 genes were redundant among genes 
Table I: Accession numbers of murine sequences used and of homolog chicken sequences found. Bold text represents chicken genes whose syntenic regions are conserved with the appropriate murine homologs.

\begin{tabular}{|c|c|c|c|c|c|c|c|c|c|}
\hline \multicolumn{4}{|c|}{ Murine genes } & \multicolumn{6}{|c|}{ Chicken genes } \\
\hline \multirow{2}{*}{$\begin{array}{l}\text { Accession } \\
\text { number }\end{array}$} & \multirow[t]{2}{*}{ Name } & \multicolumn{2}{|c|}{ Localisation } & \multirow{2}{*}{$\begin{array}{l}\text { Accession } \\
\text { number }\end{array}$} & \multirow[t]{2}{*}{ Name } & \multirow{2}{*}{$\begin{array}{l}\text { tblastn } \\
\text { score }\end{array}$} & \multicolumn{2}{|c|}{ Localisation } & \multirow[t]{2}{*}{ abbreviation } \\
\hline & & Chromosome & Position (kb) & & & & Chromosome & Position (kb) & \\
\hline XM_205433.2 & Oog2-like & $4 \mathrm{EI}$ & 142170 & XM_4I7634 & similar to zinc finger protein RIZ. partial & 100 & 21 & 4843 & $\underset{\mathbf{Z}}{\text { znfingerRI }}$ \\
\hline XM_357I75.2 & $\begin{array}{l}\text { TRAF- } \\
\text { interacting } \\
\text { protein }\end{array}$ & $2 \mathrm{AI}$ & 6081 & XM_4I6727 & similar to mtprd protein - mouse & 102 & 1 & 100734 & mtprd \\
\hline AK054339.I & $\mathrm{FBXO} / 2 \mathrm{~A}$ & $9 F 2$ & 109192 & XM_419103 & similar to hypothetical protein & 104 & 2 & 91887 & fbox \\
\hline AY35159I.I & Msh4 & $3 \mathrm{H} 3$ & 154505.7 & XM_422549 & similar to MutS homolog 4 & 107 & 8 & 29983 & msh4 \\
\hline XM_I38939.3 & Speer-like & $14 \mathrm{A3}$ & 20635 & XM_421604 & similar to Discs. large homolog 5 & 132 & 6 & 12497.5 & $\operatorname{discs} 5$ \\
\hline AK0I836I.I & Zfp393 & $4 \mathrm{D} 2$ & 116103.6 & XM_422416 & $\begin{array}{l}\text { similar to Kruppel-like transcription factor } \\
\text { neptune }\end{array}$ & 288 & 8 & 20700.7 & ktfn \\
\hline NM_I7248I.I & Nalp9E & $7 \mathrm{AI}$ & 5473.6 & XM_42095I & $\begin{array}{l}\text { similar to mast cell maturation inducible } \\
\text { protein I }\end{array}$ & 473 & 5 & 3008 & mcmip \\
\hline BC0668II.I & Btg4 & $9 \mathrm{~A} 5$ & 51279 & XM_417919 & similar to $\mathrm{p} 30 \mathrm{~B} 9.10$ & 599 & 24 & 5212.7 & btg 4 \\
\hline XM_355960.I & PAR-IAlike & $7 A 3$ & 11760.3 & XM_421385 & $\begin{array}{l}\text { similar to MAP/microtubule affinity- } \\
\text { regulating kinase } 3 \text { long isoform }\end{array}$ & 643 & 5 & 47042.5 & mark3 \\
\hline AYI9I4I5.I & Zarl & 5 & 72968 & XM_424318 & Gallus gallus similar to zygote arrest I & 643 & 4 & 68326.1 & zarl \\
\hline$X M_{-} 139155.2$ & & I4D3 & 71005 & XM_416218 & similar to transcription factor 20 isoform I & 688 & 1 & 46012.9 & $\begin{array}{c}\text { transfact2 } \\
0\end{array}$ \\
\hline NM_010021.2 & Dazl & $|7 B|$ & 48475 & NM_204218 & deleted in azoospermia-like & 863 & 2 & 33589.4 & dazL \\
\hline NM_02002I.I & Mos & $4 \mathrm{Al}$ & 3798.4 & MI94I2 & Chicken c-mos proto-oncogene & 955 & 2 & 110418 & chkmos \\
\hline NM_0II 775.2 & ZP2 & $7 F 2$ & 107432.5 & XM_424608 & similar to zona pellucida $A$ & 1146 & 6 & 15797.3 & zpA \\
\hline NM_201370.I & WEEIhu & $6 \mathrm{BI}$ & 40383 & XM_42549I & similar to Wee IA kinase & 1218 & 1 & 54018.4 & wee \\
\hline NM_0II776.I & ZP3 & $5 G 2$ & 133429.5 & D89097 & zona pellucida $C$ protein & 2149 & 10 & 188.600 & $\mathrm{zpC}$ \\
\hline
\end{tabular}




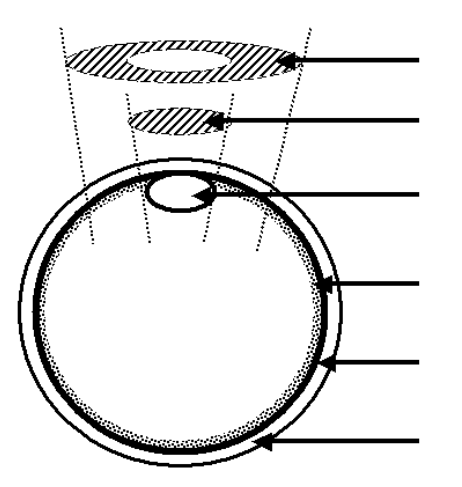

GCs

$\mathrm{GDR}=\mathrm{GD}+\mathrm{GCs}$

\section{GD}

Extra embryonic RNA

Perivitelline membrane

Granulosa layer

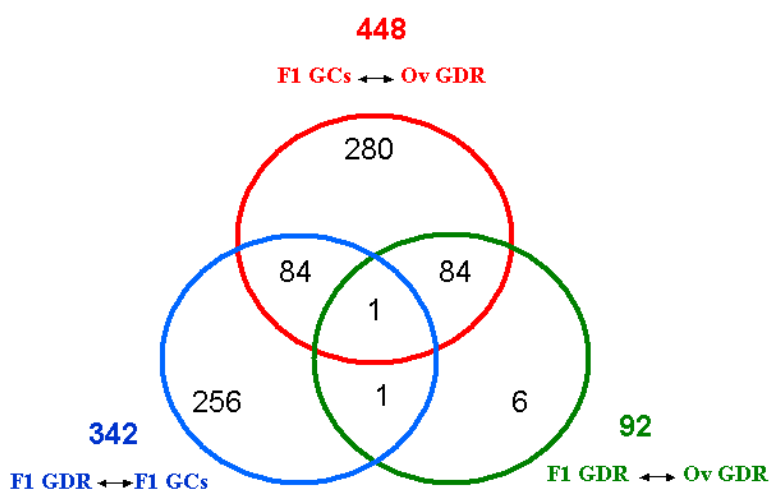

Figure I

Schematic representation of avian oocyte. The oocyte is delimited by the perivitelline membrane, and the overlying layer of granulosa cells (GCs). Inside the oocyte, the perivitelline membrane is covered by extra-embryonic RNA. At the top of the oocyte, the germinal disc (GD) is visible. The GD with the overlying GCs constituted the germinal disc region (GDR). Two hatched area represent two different samples used in this study. The GDR comprises the GD and the lowest possible number of GCs, and GCs comprises by the GCs located in the vicinity of the GDR. Both samples are localized on the apical part of the oocyte.

overexpressed in the Ov GDR and F1 GCs, and F1 GDR and F1 GCs comparisons.

Based on GO annotation the genes upregulated in GCs were mostly related to metabolic processes, transport, proteolysis, regulation of transcription, immune response and cell adhesion, whereas genes preferentially expressed in GDR were preferentially involved in cell cycle, chromosome organization, phosphorylation of proteins, regulation of transcription, multicellular organism development and DNA metabolic processes (Fig. 4).

\section{Tissular pattern of gene expression}

On the basis of the in silico and microarray approaches, 17 genes were retained for further study. Among these, 16 genes were found using the in silico approach as described above (Table 1), of which 6 genes (chkmos, dazL, btg4, zpA, $k t f n$ and $z p C$ ) were also found using the microarray approache (Table 2) and 1 gene $(z p D)$ was found only in the microarray approach. The latter gene was chosen because of its strong involvement in the fertilization process [31]. In contrast to $z p A$ and $z p C$, the $z p D$ gene was not found in the mouse [32], explaining why it was absent from the list of murine potentially oocyte-specific genes. Four other genes already known for their involvement in

\section{Figure 2}

The relationships between differentially expressed genes in different comparisons. Diagram shows the overlap of differentially expressed genes in different comparisons. Each circle represents the total number of differentially expressed genes in one comparison. The overlapping areas represent differentially expressed genes common for different comparisons.

final follicular maturation or early embryo development in the chicken or in other vertebrates were added (foxL2 [33], igf2 [34,35], hsf1 [36], and cvh [23]) (Table 3). Finally 21 chicken genes were further studied. Real time RT-PCR performed on 11 adult tissue samples (total ovary, spleen, intestine, gizzard, liver, heart, skin, brain, pectoralis muscle, lung and pituitary gland) revealed differences in the specificity of their tissular expression patterns. Tissular expression profiles of some of these genes are presented on Fig. 4. Seven of these genes (dazL, wee, $z a r 1, z p A, b t g 4, z p C$ and chkmos) were specifically expressed in the ovary (Fig 5A). The specificity of $z p C$ and chkmos has previously been described and our results concerning these genes (data are not shown) were in accordance with the literature ([37] and [38], respectively). Eight genes were preferentially and strongly expressed in the ovary (Fig. 5B). Three genes from last group were slightly expressed in another tissue: fbox and $z p D$ in the pituitary gland and $k t f n$ in the muscle. We also confirmed preferential ovarian expression of $c v h$ [23] and foxL2 [33], as well as a low expression of the latter in the pituitary gland (data not shown). Three other genes from this group (igf2, mark3 and znfingerRIZ) were slightly expressed in other tissues, in addition to the ovary. The last 6 genes (trans fact 20, msh4, mtprd, mcmip, discs 5 and $h s f 1$ ) were expressed as highly in the ovary as in other tissues (data not shown). 


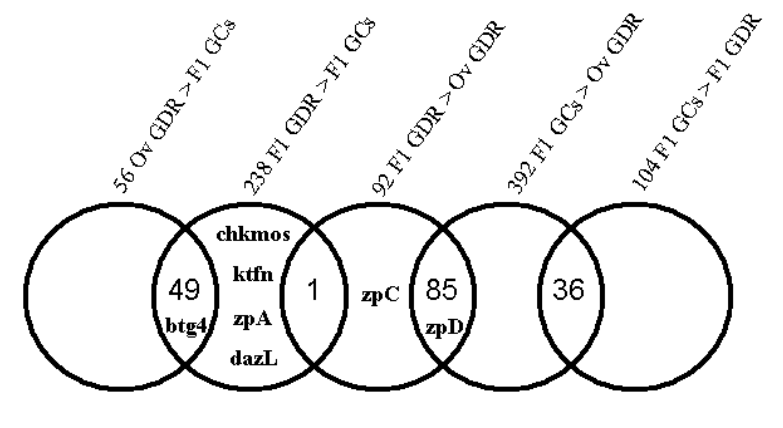

Figure 3

The relationships between overexpressed genes in different comparisons. Diagram shows the overlap of overexpressed genes in different comparisons. Each circle represents the total number of overexpressed genes in one comparison. The overlapping areas represent overexpressed genes common for different comparisons. Genes identified by the in silico approach and found to be overexpressed in different comparisons on the chips are indicated.

\section{RNA state during follicular maturation and early embryo} development

Analysis of total RNA, assessed with Agilent RNA nano chips (Fig. 6A), showed an atypical state of RNA from GDR between ovulation and oviposition. In our conditions, rRNA seemed degraded from ovulation until oviposition. With three different RNA extraction methods (tri reagent (Euromedex), RNeasy kit (QIAGEN) and MasterPure $^{\mathrm{TM}}$ RNA Purification Kit (Epicentre Biotechnologies)), the RNA profile of GDR from the ovulation stage and from the following embryonic stages remained degraded (data not shown). Moreover, we assessed rRNA 18S and $28 \mathrm{~S}$ by real time PCR in order to confirm this atypical RNA state (Fig. 6B and 6C). These results confirmed our previous observations; $18 \mathrm{~S}$ and $28 \mathrm{~S}$ rRNA expression showed a huge decrease from ovulation untill the oviposition. We then performed labelled reverse transcription to investigate whether mRNA was also degraded. We compared three samples, i.e. the RNA from GDR of F1 stage, from a whole adult ovary that had a normal rRNA profile and GDR of ovulation stage with had degraded rRNA. Electrophoresis profiles of labelled cDNA in denaturing agarose gel were almost identical for the three samples investi- gated and the smear corresponding to the reverse transcribed mRNA was still present in all these samples (Fig. 6D).

\section{Gene expression during follicular maturation and early embryo development}

A detailed study of the expression profiles during follicular maturation and early embryo development using real time RT-PCR was performed for 21 genes, for which tissue specificity of the expression was characterized. First unsupervised hierarchical clustering of our data was performed in order to confirm the biological appropriateness of the selected genes and samples (Fig 7). Two other previously studied genes ( $g d f 9$ and $b m p 15$ ) were added to this analysis in order to facilitate the clustering process because of their already known oocyte-preferential localization [30]. This analysis discriminated two major groups of samples. The first included all granulosa samples from F6 to F1 (correlation threshold 0.58 ). The second group corresponded to GDR from F6 to the ovulation stage and to all embryo stages (correlation threshold 0.60). Several subgroups could be distinguished within each group (correlation threshold 0.69-0.94). Each subgroup corresponded to a different physiological state, indicated on Fig 6A, suggesting that the genes selected were pertinent. Moreover, unsupervised clustering arranged samples in the perfect chronological order.

In order to group genes with similar expression patterns supervised clustering was performed with samples arranged first according to the nature of the sample (GCs or GDRs) and then according to chronological order (Fig. 8 ). Five clusters (threshold $>0.64$ ) were identified (C1 to C5). A representative example of the expression profile characterizing each cluster is shown on Fig. 9. The graphical representation of expression profiles of all other genes with the corresponding statistical analysis of variation of their expression is supplied in additional files (see Additional file 1, 2, 3 and 4). The chkmos, btg4, wee, zpA, dazL, $h s f 1$, fbox and bmp15 genes, forming cluster C1, were preferentially expressed in GDR. These genes showed a significant increase in mRNA expression in GDR during follicular maturation and a steady decrease after ovulation, becoming nearly undetectable at $36 \mathrm{~h}$ after fertilization. The c vh, ktfn and zar1 genes included in Cluster C2 were also preferentially expressed in GDR but, in contrast

Table 3: Accession number of chicken genes selected on the basis of the literature

\begin{tabular}{|c|c|c|c|}
\hline Bibliographic reference & Accession number & Name & Abbreviation \\
\hline Govoroun et al. 2004 & NM_001012612 & forkhead box L2 & foxL2 \\
\hline Aegerter et al. 2005, Heck et al. 2005 & XM_421026 & Insulin growth factor 2 & $\lg 2$ \\
\hline Tsunekawa et al. 2000 & NM_204708 & Gallus gallus DEAD (Asp-Glu-Ala-Asp) box polypeptide 4 (DDX4) & cvh \\
\hline Hsfl Anckar et al. 2007 & L06098 & chicken heat shock factor protein I & hsfl \\
\hline
\end{tabular}




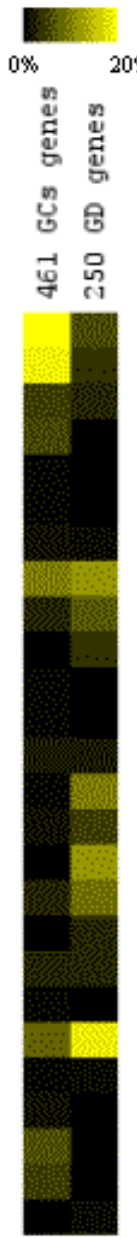

\begin{tabular}{|c|c|c|c|}
\hline $\begin{array}{c}\text { Number of genes } \\
\text { differentially expressed } \\
711\end{array}$ & $\begin{array}{c}\text { Not annotated } \\
\text { genes }\end{array}$ & $\begin{array}{c}\text { Annotated } \\
\text { genes } \\
40 \%\end{array}$ & $\begin{array}{c}\text { Genes linked } \\
\text { to a function }\end{array}$ \\
$60 \%$ & $34 \%$ \\
\hline
\end{tabular}

transport

metabolic process

biosynthetic process

proteolysis

glycolysis

cytolysis

apoptosis

regulation of transcription

DHA replication

DHA recombination

translation

protein secretion

protein modification process

microtubule-based movement

multicellular organismal development

chromosome organization

cell cycle

cell communication

signal transduction

SRP-dependent cotranslational protein targeting to membrane

protein amino acid phosphorylation

intracellular signaling cascade

regulation of cell growth

cell adhesion

immune response

gonad development

\section{Figure 4}

Gene ontology (GO) classification of genes overexpressed in GDR of mature oocytes and in FI GCs identified using Affymetrix microarray analysis. The rows represent percentages of genes linked to a function calculated from a total number of genes linked to any function. The columns present sets of genes overexpressed in different cell layers. GO annotations were found with Netaffx software, as described in Materials and Methods.

to genes from cluster $\mathrm{C} 1$, they were constantly expressed in the early embryo. Moreover, $k t f n$ and zar1 genes displayed a significant increase in expression from 24 to 48 hours after fertilization. The genes from cluster C3 were expressed in GCs, in GDRs and in the embryo. Moreover, mark3, igf2, gdf9 and transfact20 genes showed a significant decrease in expression during the last stages of follicular maturation in both GDR and GCs. Cluster C4, including discs5, znfingerRIZ, foxL2 and mtprd genes, was characterized by expression that was fairly similar to that of cluster C3. The difference consisted of less pronounced variations in gene expression in GCs and more pronounced variations in gene expression in GDR for cluster $\mathrm{C} 4$ compared to genes in cluster $\mathrm{C} 3$ through the stages investigated. Genes belonging to cluster C5 were expressed in GCs and GDR but, in contrast to the clusters
C3 and C4, their expression dropped dramatically at ovulation, especially for $z p C$ and $z p D$ whose transcripts showed increasing expression in GCs during the last stages of follicular maturation and a less marked increase in the expression in GDR. In contrast, the levels of mcmip decreased progressively during the same period. The last gene ( $m s h 4)$ was not clustered. Its expression profile was fairly similar to that of genes belonging to cluster C3, but its expression increased significantly $36 \mathrm{~h}$ after fertilization.

\section{Localization of gene expression in the ovary by in situ hybridization}

We performed in situ hybridization on mature and immature ovarian sections. All the probes were assessed on the two stages, but only the most significant results are shown 
Table 2: Genes differentially expressed in Affymetrix experiment. Bold text represents genes that were further studied using real time RT-PCR

\begin{tabular}{|c|c|c|c|c|c|c|}
\hline Affymetrix reference & Accession number & Gene name found by Blast search & Abbreviation of genes studied & Fold change & Comparison & Number of overexpressed genes \\
\hline Gga.305.I.SI_at & NM_204783.I & Gallus gallus wingless-type MMTV integration site family, member 4 & & 150 & $\mathrm{FI} G \mathrm{G}$ and $\mathrm{Or}$ GDR & 56 genes overexpressed in Ov GDR \\
\hline GgaAffx.13126.I.SI_at & Aj721023 & Gallus gallus mRNA for hypothetical protein, clone 3212 & & 129 & & \\
\hline Gga.5341.I.S1_at & BU365377 & Finished cDNA, clone ChEST746h6 & & 105 & & \\
\hline Gga.7980.I.SI_at & CD73024I & similar to Interferon regulatory factor 6 & & 102 & & \\
\hline Gga.4536.2.SI_a__at & BX934646.1 & $\begin{array}{l}\text { aldo-keto reductase family I, member DI (delta 4-3-ketosteroid-5-beta- } \\
\text { reductase) }\end{array}$ & & 94 & & \\
\hline Gga.9136.2.SI_a_at & CD740066 & Gallus gallus tumor-associated calcium signal transducer I & & 92 & & \\
\hline GgaAffx.11525.I.SI_s_at & AJ719422 & Gallus gallus claudin I & & 91 & & \\
\hline GgaAffx.20379.I.SI_at & CR524236.I & Finished cDNA, clone ChEST91403 & & 90 & & \\
\hline Gga.9936.I.SI_at & BX936026.2 & $\begin{array}{l}\text { Amyotrophic lateral sclerosis } 2 \text { chromosomal region candidate gene } \\
\text { protein } 7\end{array}$ & & 83 & & \\
\hline Gga.5597.1.SI_at & BU450II5 & B-cell translocation gene 4 & btg 4 & 52 & & \\
\hline Gga.14454.I.SI_at & NM_213576.1 & zona pellucida protein $\mathrm{D}$ & zpD & 890 & $\mathrm{FI} \mathrm{GCs}$ and Ov GDR & 392 genes overexpressed in FI GCs \\
\hline Gga.12391.I.SI_at & BX935169.2 & Gallus gallus similar to adrenodoxin homolog & & 718 & & \\
\hline Gga. 1824.I.SI_at & BU350625 & Gallus gallus finished cDNA, clone ChEST974b 18 & & 703 & & \\
\hline Gga.6358.I.SI_at & BX265773 & Gallus gallus similar to chromosome 9 open reading frame 61 & & 687 & & \\
\hline Gga.596.1.S2_at & NM_205118.1 & $\begin{array}{l}\text { Gallus gallus 3beta-hydroxysteroid dehydrogenase/delta5-delta4 } \\
\text { isomerase }\end{array}$ & & 667 & & \\
\hline Gga.17706.I.SI_at & CR388473.I & Gallus gallus finished cDNA, clone ChEST59|gII & & 579 & & \\
\hline Gga.3095.I.SI_a_at & BX932425.2 & similar to hypothetical protein FL/22662 & & 561 & & \\
\hline Gga.13065.I.SI_at & BU424424 & Gallus gallus finished cDNA, clone ChEST537h2I & & 559 & & \\
\hline GgaAffx.5954.I.SI_at & ENSGALT00000015374.1 & Gallus gallus similar to LRTS84I & & 557 & & \\
\hline GgaAffx.24194.I.SI_at & ENSGALT00000021874.I & Gallus gallus similar to CG8947-PA & & 534 & & \\
\hline Gga.305.I.SI_at & NM_204783.I & Gallus gallus wingless-type MMTV integration site family, member 4 & & 90 & $\mathrm{FI} G D R$ and $\mathrm{FI} G \mathrm{GS}$ & 238 genes overexpressed in FI GDR \\
\hline Gga.7980.I.SI_at & CD73024I & similar to Interferon regulatory factor 6 & & 80 & & \\
\hline Gga.6103.1.SI_x_at & BU242707 & Gallus gallus similar to CG31613-PA & & 75 & & \\
\hline Gga.490I.I.SI_at & BU424477 & Gallus gallus similar to carbonic anhydrase 9 & & 72 & & \\
\hline Gga.9136.2.5I_a_at & CD740066 & Gallus gallus tumor-associated calcium signal transducer I & & 66 & & \\
\hline Gga.5133.1.SI_at & NM_204218.1 & Gallus gallus deleted in azoospermia-like & dazL & 34 & & \\
\hline Gga.5597.I.SI_at & BU450II5 & B-cell translocation gene 4 & btg4 & 33 & & \\
\hline Gga.8089.1.SI_at & BU258896 & Gallus gallus similar to Kruppel-like transcription factor neptune & ktfn & 18 & & \\
\hline Gga.5714.I.SI_at & BX268842 & Gallus gallus similar to zona pellucida $A$ & zрA & 12 & & \\
\hline GgaAffx.9819.1.SI_at & ENSGALT0000002485 I.I & oocyte maturation factor Mos & chkmos & 10 & & \\
\hline Gga.9254.I.SI_at & CF384921 & & & 120 & FI GDR And FI GCs & 104 genes overexpressed in FI GCs \\
\hline GgaAffx.96.1.SI_s_at & ENSGALT00000000192.1 & Gallus gallus similar to CG8947-PA & & 68 & & \\
\hline Gga.12454.I.SI_at & BU435007 & similar to relaxin 3 preproprotein & & 68 & & \\
\hline Gga.II03I.I.SI_at & BU450054 & Gallus gallus finished cDNA, clone ChEST699k2 & & 56 & & \\
\hline GgaAffx.24194.I.SI_at & ENSGALT00000021874.1 & Gallus gallus similar to CG8947-PA & & 31 & & \\
\hline Gga.572.I.SI_at & NM_205078.I & Gallus gallus nuclear receptor subfamily 5, group $A$, member 2 & & 27 & & \\
\hline Gga.10434.I.SI_at & BX933855.1 & Gallus gallus similar to chromosome 9 open reading frame 61 & & 19 & & \\
\hline Gga.45I0.I.SI_a_at & NM_205261.I & Gallus gallus finished cDNA, clone ChESTI5908 & & 17 & & \\
\hline Gga.7212.1.SI_at & BUI24346 & Gallus gallus similar to EphxI protein & & 14 & & \\
\hline Gga.3667.I.SI_at & NM_204839.I & Gallus gallus reversion-induced LIM protein & & 13 & & \\
\hline Gga. 14454.I.SI_at & NM_213576.1 & Gallus gallus zona pellucida protein $\mathrm{D}$ & zpD & 602 & FI GDR And Ov GDR & 92 genes overexpressed in FI GDR \\
\hline Gga.12391.I.SI_at & BX935169.2 & similar to adrenodoxin homolog - chicken & & 321 & & \\
\hline Gga.596.I.S2_at & NM_205118.1 & $\begin{array}{l}\text { Gallus gallus 3beta-hydroxysteroid dehydrogenase delta5-delta4 } \\
\text { isomerase }\end{array}$ & & 317 & & \\
\hline Gga.17706.I.SI_at & CR388473.I & Finished cDNA, clone ChEST59|gl। & & 307 & & \\
\hline GgaAffx.5954.I.SI_at & ENSGALT00000015374.1 & similar to LRTS84I & & 247 & & \\
\hline Gga.6358.I.SI_at & BX265773 & weak similarity to HUMAN Putative protein $\mathrm{X} \mid 23$ & & 240 & & \\
\hline Gga.1824.I.SI_at & BU350625 & Finished cDNA, clone ChEST974b 18 & & 213 & & \\
\hline Gga.13065.I.SI_at & BU424424 & Finished cDNA, clone ChEST738j4 & & 195 & & \\
\hline Gga.3095.I.SI_a_at & BX932425.2 & similar to hypothetical protein FLJ22662 & & 183 & & \\
\hline Gga.7210.1.SI_at & NM_204389.1 & Gallus gallus zona pellucida glycoprotein 3 & zpC & 64 & & \\
\hline
\end{tabular}




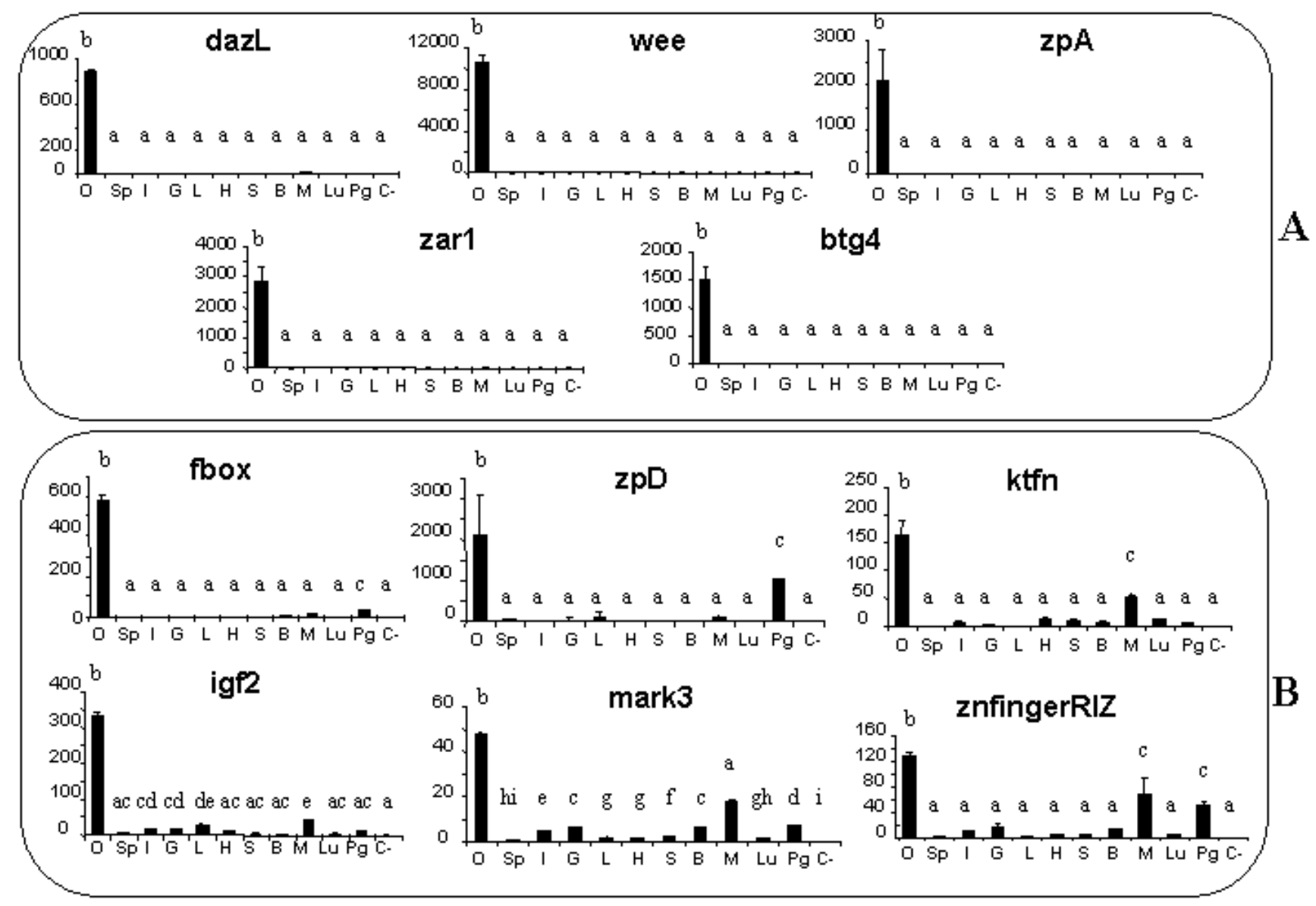

Figure 5

Real-time PCR analysis of the expression of candidate genes in hen tissues. Total RNA was isolated from whole ovary $(\mathrm{O})$, spleen $(\mathrm{Sp})$, intestine $(\mathrm{I})$, gizzard $(\mathrm{G})$, liver $(\mathrm{L})$, heart $(\mathrm{H})$, skin $(\mathrm{S})$, brain $(\mathrm{B})$, pectoralis muscle $(\mathrm{M})$, lung $(\mathrm{Lu})$ and pituitary gland $(\mathrm{Pg})$ and real time PCR was performed as described in the Materials and Methods. Ribosomic RNA I8S was used as a reporter gene. The negative control (water) is indicated as (C-). The results represent the means \pm SEM. The same letters indicate that differences were not significant. Different letters indicate that differences were significant $(p<0.05)$.

on Fig. 10. For all the genes studied we detected homogeneous signals of mRNA expression in oocytes similar to those we have previously described for bmp15 and gdf9 [30]. The mRNA of four of eight genes localized by in situ hybridization (btg4, dazL, cvh and fbox) were detected with a high intensity signal in the oocytes from follicles of 300 $\mu \mathrm{m}-600 \mu \mathrm{m}$ from both immature (Fig. 10A,B,C and 10D) and mature (data not shown) ovaries. No significant expression was detected in somatic cells. For four other genes (chkmos, $z p A, z p C$ and $z p D$ ) a signal was found in oocytes from the largest follicles of $500 \mu \mathrm{m}-6 \mathrm{~mm}$ of mature ovaries (Fig. 10E,F,G and $10 \mathrm{H}$ ). The signal was particularly high for chkmos and $z p A$ (Fig. 10E and 10F), whereas $z p C$ and especially $z p D$ had weaker signals in both oocyte and somatic cells (Fig. 10G and 10H). No sig- nificant signal was detected with the corresponding sense probes.

\section{Discussion}

In the present study we identified and characterized for the first time several genes expressed in the chicken oocyte during follicular maturation and/or in early embryo. Moreover, we showed that our candidate gene approach and microarray approach were complementary in finding new avian genes potentially involved in follicular maturation and/or early embryo development. Five genes preferentially and highly expressed in the oocyte (btg4, chkmos, $d a z L, z p A$ and $k t f n$ ) were identified using both microarray analysis and digital differential display on murine genes. Moreover, 2 genes ( $z p C$ and $z p D$ ), identified as overex- 

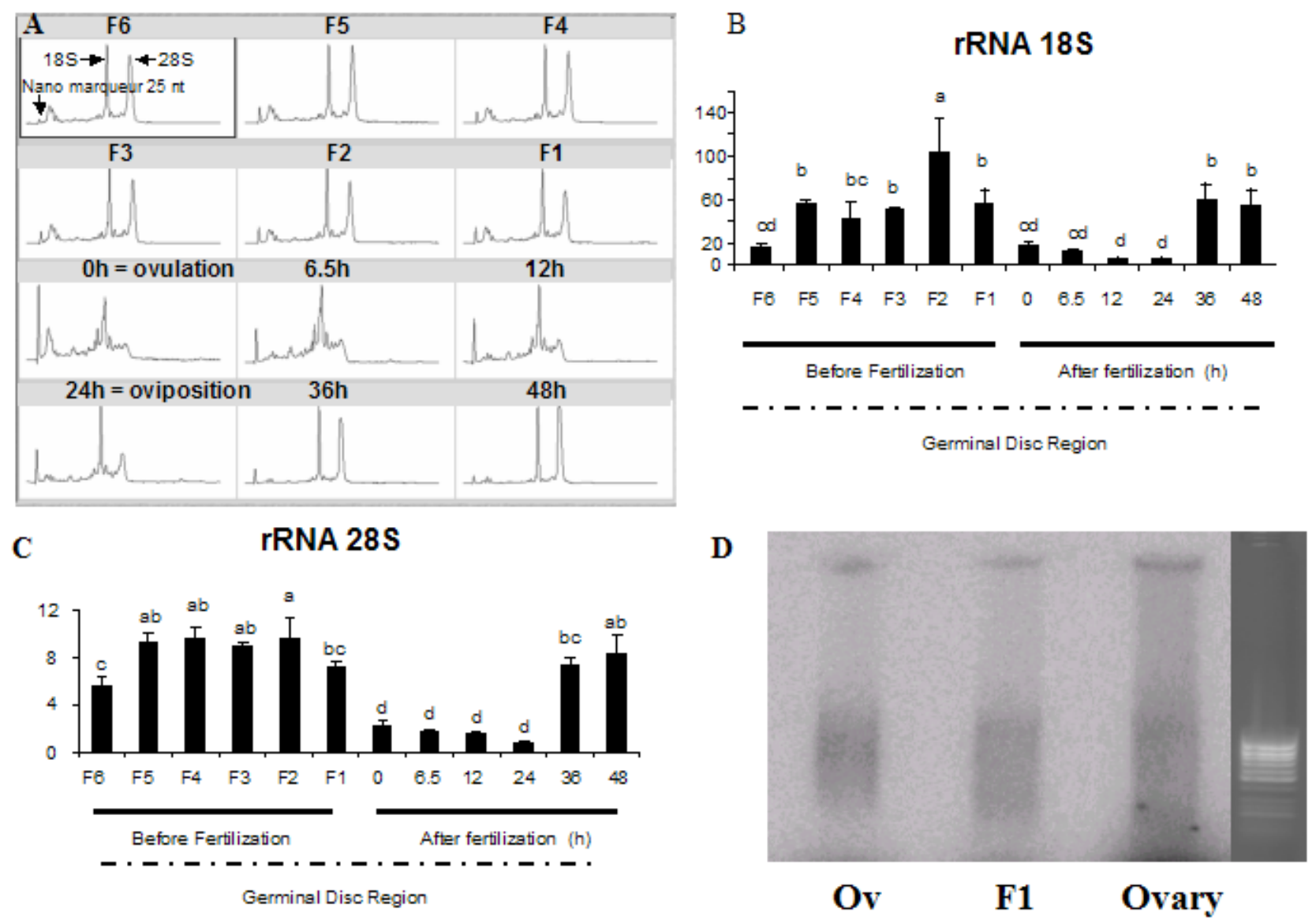

\section{Figure 6}

Ribosomic and messenger RNA profiles during oocyte maturation and early embryo development. Total RNA was extracted from the GDR of an oocyte or from the embryo. RNA quality was assessed using nanochips (Agilent technologies) as described in the Materials and Methods. This analysis represents rRNA I8S and 28S subunit profiles in the samples (A). Ribosomic RNA 18S and 28S subunit profiles were then confirmed by real time PCR analysis (B and C, respectively) using the TaqMan kit (Eurogentec) as described in the Materials and Methods. Labelled ${ }^{32} \mathrm{P}$ reverse transcription was performed to investigate the quality of mRNA extracted from FI GDR, Ov GDR and from the ovary. The radioactive signal for samples and ethidium bromide staining for the ladder are shown (D).

pressed in GCs by microarray analysis, were also confirmed by real time PCR analysis to be highly preferentially expressed in chicken GCs compared to GDR. Microarray analysis identified a total of 245 genes upregulated in the hen F1 and ovulated oocytes both compared to F1 GCs. Among these, 49 overexpressed genes were common to Ov GDR and and F1 GDR, both compared to F1 GCs, and therefore represent particular interesting candidate oocyte genes for further exploration of their potential role in oocyte maturation, fertilization and OET. The fact that we found almost five times fewer genes overexpressed in the oocyte at the ovulation stage (com- parison between Ov GDR and F1 GCs) than in the oocyte at F1 stage (comparison between F1 GDR and F1 GCs), compared to granulosa cells from F1 follicles, means that for some genes mRNA expression in the oocyte decreased between F1 and ovulation stages. This change in the mRNA expression levels between F1 and ovulated oocytes is probably insufficient to be detected in the comparison between Ov GDR and F1 GDR by microarray hybridization, since only 7 differentially expressed genes were identified in this comparison. On the other hand microarray analysis enabled us to detect the presence of GCs in F1 GDR samples, revealed by the redundant overexpressed 


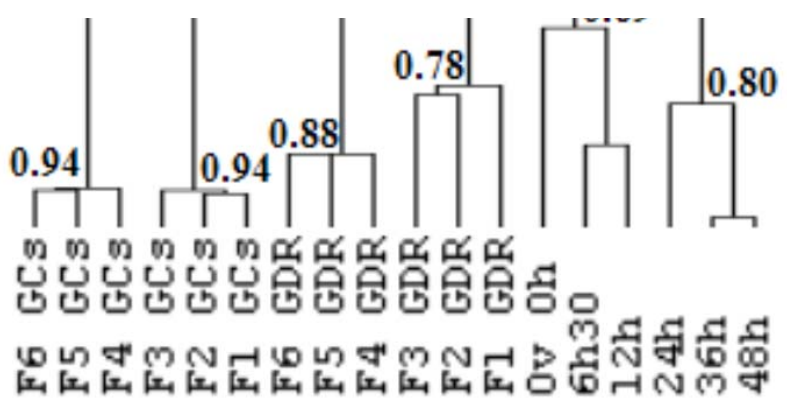

Figure 7

Unsupervised hierarchical clustering of candidate genes during follicular maturation and early embryo development. Real time PCR analysis was performed in duplicate on samples at 18 different stages with two biological replicates. Total GDR and GC RNA from different preovulatory follicles (FI to F6), and total GDR RNA from just ovulated oocytes and early embryos at $6.5 \mathrm{~h}, \mathrm{I} 2 \mathrm{~h}, 24 \mathrm{~h}, 36 \mathrm{~h}$ and $48 \mathrm{~h}$ post ovulation were extracted as described in the Materials and Methods. Unsupervised hierarchical clustering of biological samples was performed using Cluster 3.0 software as described in the Materials and Methods. Node correlation thresholds are indicated.

genes in F1 GDR and in F1 GCs compared to Ov GDR. The functions of overexpressed genes in the various comparisons according to GO categories revealed clear differences between GCs and mature oocytes. For GCs overexpressed genes these functions were mostly related to metabolic processes, transport, proteolysis, regulation of transcription, immune response and cell adhesion, whilst for the mature oocyte they were mostly related to cell cycle, chromosome organization, phosphorylation and dephosphorylation of proteins, multicellular organism development and DNA metabolic process. These presumed functions of genes overexpressed in the oocyte are consistent with the physiological processes that it must undergo: i.e. fertilization, cleavage, chromatin remodeling, and supporting early embryo development.

The use of both bioinformatics and microarray approaches provided information on the molecular mechanisms through which OET is driven in the hen. The expression of several oocyte-specific genes increased during final follicular maturation, suggesting that transcription was still effective. After ovulation, despite the fact that $18 \mathrm{~S}$ and $28 \mathrm{~S}$ ribosomal RNA subunits were degraded, we showed by both labelled reverse transcription and microarray analysis that the integrity of mRNA was almost unaffected. In fact, mRNA levels were nearly the same for many genes because only 92 of 28000 genes were differentially expressed between GDRs before and after ovulation, of which only 7 really corresponded to the oocyte genes. The high number of replicates performed and the different extraction methods used strongly indicate that the difference in quality between oocyte rRNA and mRNA after ovulation is not the artifact of the experiment but reflects a real physiological feature of chicken OET, consisting probably of the arrest and degradation of the oocyte translational machinery. It could thus be hypothesized that the maternal translational system has to be replaced by the embryonic translational system. Indeed, the maternal ribosome in the embryo must be degraded before activation of the genome, in other words, before the beginning of transcription, and translation, when new embryonic ribosomes are required. This suggests that, because there are no maternal ribosomes at the stage between ovulation and oviposition, there is probably no translation or only translation of a few specific genes. If this is the case, maternal proteins should be the major essential components that support early embryo development after fertilization. This is supported by the fact that, based on GO annotation, a considerable number of the genes overexpressed in the mature oocyte are related to protein phosphorylation. Further investigation is required onto whether accumulated proteins have such an important role during these early stages of development in birds or if de novo protein synthesis still occurs and is dependent on the oocyte pool of ribosomes as in mammals [39].

On the basis of in silico and microarray approaches and analysis of the literature, 21 chicken genes were chosen in this study for further investigation of their expression using real time PCR and in situ hybridization. All these genes showed state-specific and/or cell type-specific expression patterns throughout the period, beginning from the first stages of final follicular maturation until embryonic genome activation. This suggests that these genes have different functions and have a role at the different physiological stages investigated. The observed decrease in the mRNA expression of almost all genes studied between ovulation and oviposition, which corresponds to late genome activation in chicken embryo [13], is consistent with a potential arrest of transcription and progressive maternal mRNA degradation occurring during meiotic maturation [40]. However, the rate of maternal mRNA degradation in the chicken seems to be considerably lower than that of rRNA, as demonstrated by the present study. Five genes (chkmos, btg4, wee, dazL and $z p A$ ) belonging to cluster C1 (Fig. 6B) were no longer expressed after activation of the embryonic genome, and thus transcripts of these genes are only maternally inherited. Moreover, chkmos, btg 4 and wee genes are known to be involved in the cell cycle in other species. In our study these maternally inherited genes were increasingly expressed during follicular maturation and thus are probably used during the last stages of final follicular maturation and/or early embryo development. Chkmos is the chicken homolog of 


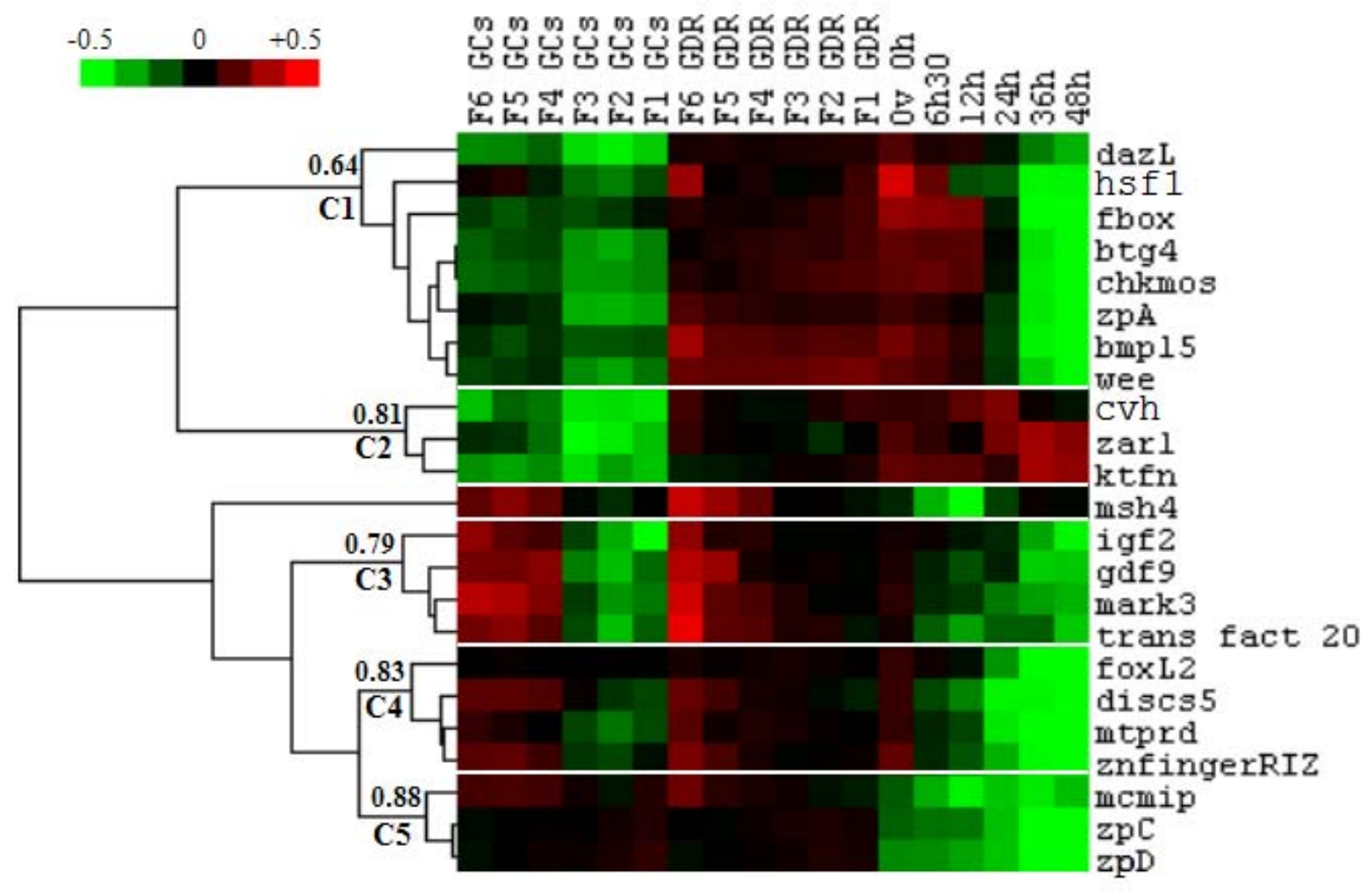

Figure 8

Supervised hierarchical clustering of candidate genes during follicular maturation and early embryo development. Real time PCR analysis was performed in duplicate on samples at 18 different stages with two biological replicates. Total GDR and GC RNA from different preovulatory follicles (FI to F6), and total GDR RNA from just ovulated oocytes and early embryos at 6.5 h, 12 h, 24 h, 36 h and 48 h post ovulation were extracted as described in the Materials and Methods. Supervised hierarchical clustering of genes was performed using Cluster 3.0 software as described in the Materials and Methods. Five clusters are shown $(\mathrm{Cl}$ to $\mathrm{C5})$. Node correlation thresholds are indicated for each cluster.

mos [38], protein kinase required for meiotic maturation in vertebrates [41,42] and for mitosis in Xenopus laevis [43]. Meiotic maturation is brought about by steroids using redundant pathways involving synthesis of Mos, which regulates the activity of MPF (M-phase promoting factor). The Mos-MAPK pathway has long been implicated in the arrest of mitosis in vertebrate eggs [43]. The B cell translocation gene 4 (btg 4 ) belongs to a family of cellcycle inhibitors. In the mouse and bovine, btg 4 is preferentially expressed in the oocyte $[44,45]$ where it exerts a marked antiproliferative activity, [46]. Wee is a conserved gene from invertebrates to mammals and regulates meiotic maturation during oocyte development [38,41-43]. The transcripts of $d a z L$ are also maternally inherited in the medaka embryo [47], and in adult medaka fish the expression of dazL was detected exclusively in the ovary and in the testis [48].

$Z p A, z p C$ and $z p D$, that belong to the ZP (zona pellucida) gene family, are known to be involved in oogenesis, fertilization and preimplantation development [49]. In our study the expression pattern of $z p A$ was different from that of $z p D$ and $z p C$ using both real time PCR analysis, where they were distributed in different clusters (C1 for $z p A$ and C5 for $z p D$ and $z p C$ respectively), and in situ hybridization analysis. In contrast to chicken $z p D$ and $z p C$, which were expressed in oocytes and somatic cells, chicken $z p A$ was found to be specific to the oocyte, as is the case in the 

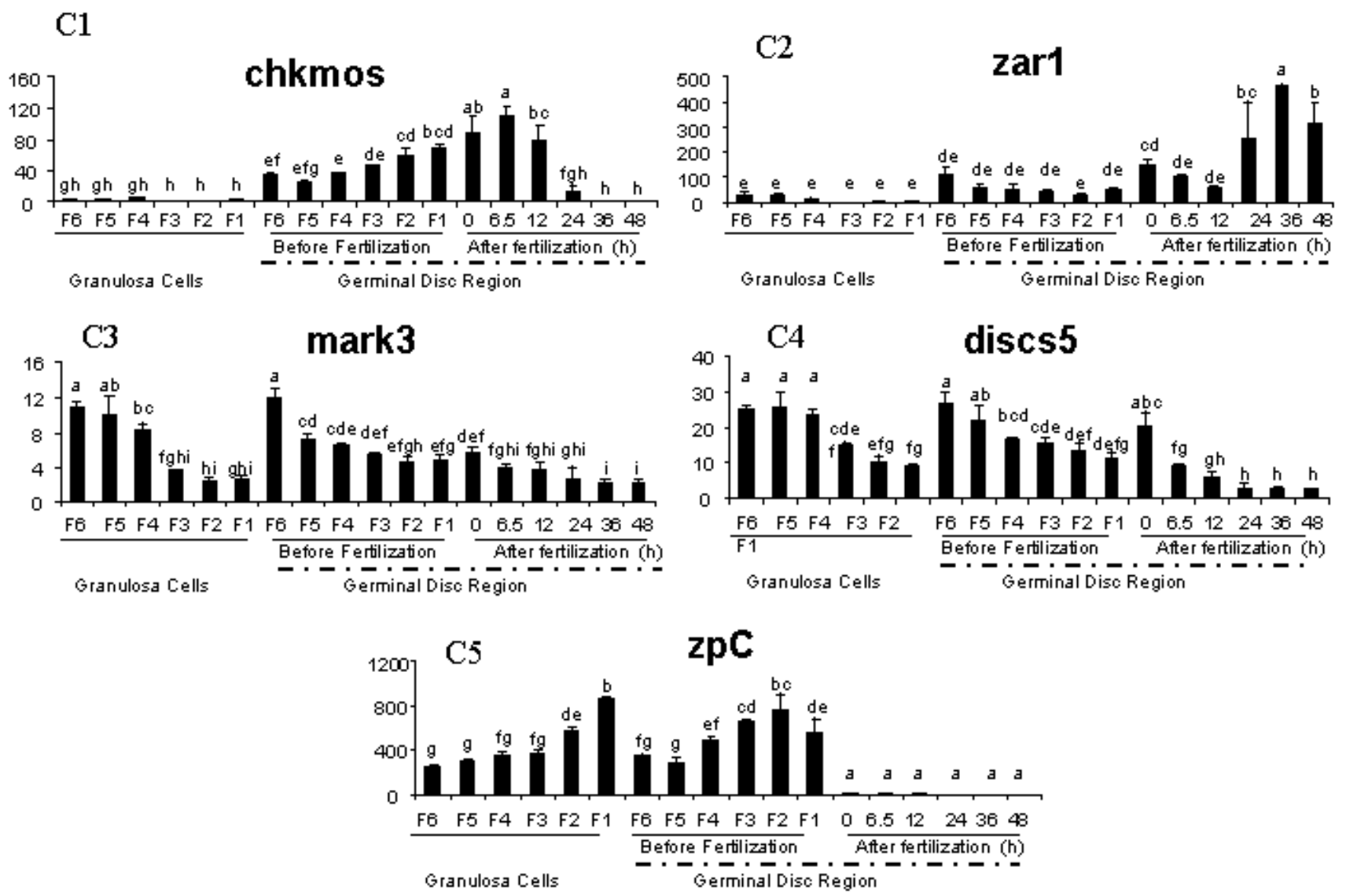

Figure 9

Expression profiles of some representative genes from 5 clusters $(\mathrm{Cl}$ to $\mathrm{C5}$ ), defined using supervised hierarchical clustering, during follicular maturation and early embryogenesis. Real time PCR analyses were performed in duplicate on samples at 18 different stages with two biological replicates. Total mRNA of GDR and GCs from different preovulatory follicles (FI to F6), and from GDR of just ovulated oocytes and early embryos at $6.5 \mathrm{~h}, 12 \mathrm{~h}, 24 \mathrm{~h}, 36 \mathrm{~h}$ and $48 \mathrm{~h}$ post ovulation were extracted as described in the Materials and Methods. Three different reporter genes were used ( $\beta$ actin, efl $\alpha$ and gapdh) because their expression was stable during oogenesis and early embryo development (data not shown). Results represent means \pm SEM. The same letters indicate that differences were not significant. Different letters indicate that differences were significant $(p<0.05)$.

mouse [50,51], and expressed earlier than $z p D$ and $z p C$. In the mouse the expression of $\mathrm{zpA}$ also precedes that of $\mathrm{zpC}$ $[50,51]$. Indeed in our in situ hybridization experiments $z p A$ expression detected in small follicles of the mature ovary was oocyte-specific, whereas that of $z p C$ and $z p D$ was weaker and found in oocytes and in the somatic cells of the same follicles. Real time RT-PCR, showed increasing expression of $z p C$ and $z p D$ in both GCs and GDR from F6 to F1. Our finding on the dynamics of $z p C$ in GCs are in accordance with a previously reported study [52].
Moreover at the F1 stage both $z p C$ and $z p D$ were significantly more highly expressed in GCs than in GD and this was consistent with our results for microarray hybridization, but expression decreased dramatically after ovulation. In contrast to the cellular expression pattern found for chicken $z p C$, in several mammals (murines, bovines and porcines $z p C(z p 3)$ is specifically expressed in the oocyte. However, in the equine species, ZPC protein synthesis is completely taken over by cumulus cells [53]. These findings indicate species specificity of $z p C$ distribu- 
A. dazL : immature ovary

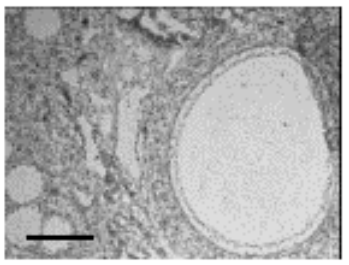

C. cvh : immature ovary
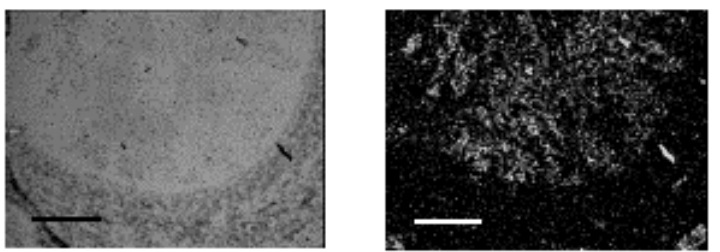

E. chkmos: mature ovary
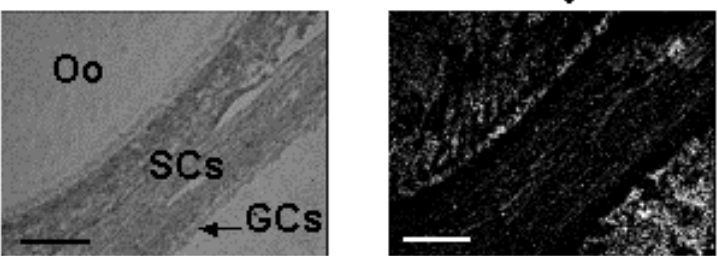

G. zpC : mature ovary
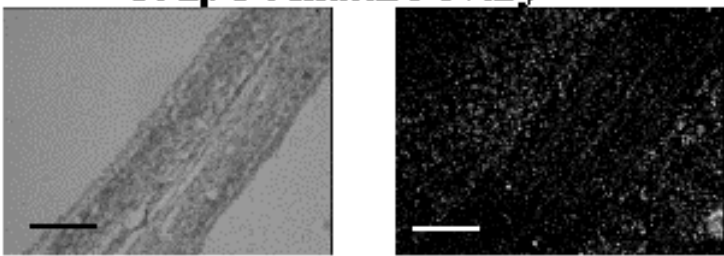

B. btg4: immature ovary
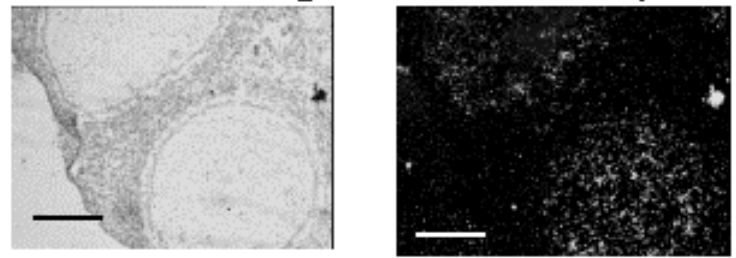

D. fbox: immature ovary
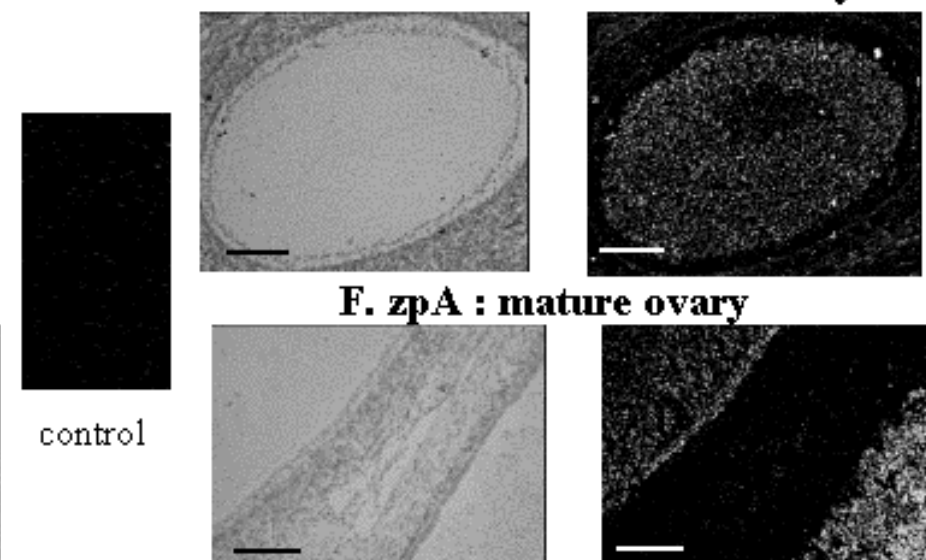

F. zpA : mature ovary

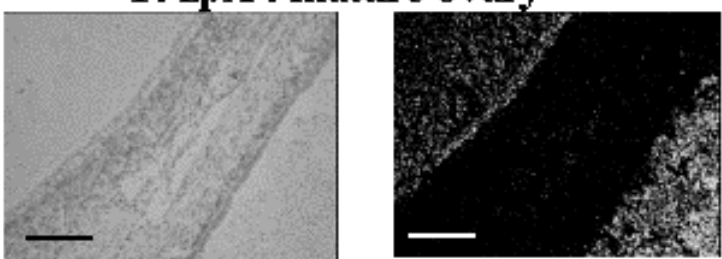

H. zpD : mature ovary
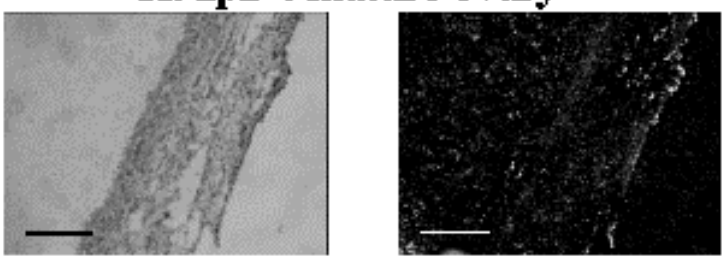

$100 \mu \mathrm{m}$

Figure 10

Localization of candidate genes mRNA in the hen ovary. Localization of dazL(A), btg4 (B), vasa (C), fbox (D), chkmos $(E), z p A(F), z p C(G)$ and $z p D(H)$ by in situ hybridization in immature ovaries $(A, B, C$ and $D)$ or in mature ovaries $(E, F, G$ and $\mathrm{H})$ as described in the Materials and Methods. Bright fields are on the left, and dark fields are on the right. The control sections were hybridized with sense probes. The hybridization with only one sense probes is represented because no signal was observed after hybridization with any sense probes. Oocytes (Oo), granulosa cells (GCs) and somatic cells (SCs) are indicated. Scale bar $=100 \mu \mathrm{m}$.

tion inside the follicle. ZPC protein plays a crucial role in the fertilization process in mammals and birds, $[31,37,49]$.

As $z p A$ other genes (zar1, $k t f n$ and $c v h$ ) were preferentially expressed in the oocyte and might play role in fertility $(z a r 1, k t f n)$ or in germ cell specification (cvh). Both zar1 and $k t f n$ were expressed at higher levels after activation of the embryonic genome. We could therefore hypothesize that these genes might be involved not only in oocyte maturation, but also in early embryo development, just after maternally inherited genes. Of these 2 genes, only $z a r 1$ has been studied in reproduction. It is one of the few known oocyte-specific maternal-effect genes essential for
OET in mice. In mammals and humans it is hypothesized to be involved in the initiation of embryo development and fertility control $[54,55]$. CVH protein has been previously proposed to be a part of the mechanism for germ cell specification in birds $[16,23]$. Our results concerning the spatio-temporal expression of $c v h$ mRNA during follicular maturation and early embryo development are consistent with previously reported studies on the $\mathrm{CVH}$ protein.

The genes belonging to clusters $\mathrm{C} 3$ and $\mathrm{C} 4$ were all preferentially expressed in the ovary in both GCs and GDR and had quite similar expression patterns. Except for foxL2, their expression declined during follicular maturation in 
GCs and less in GDR and persisted at low levels in the early embryo. This suggests that they are especially involved in the first stages of final follicular maturation as well as in oocyte maturation. The chicken homolog of the mouse par-1a-like gene, i.e. mark3, is required for oocyte differentiation and microtubule organization in the Drosophila [56], and its role in cell polarity and Wnt signaling is conserved from invertebrates to mammals $[57,58]$. The expression of another gene ( $m s h 4)$, which did not belong to any cluster, also decreased during follicular maturation in GCs and in GD but, as for zar1 and ktfn, it showed a significant increase after embryonic genome activation. Msh4 is known to be involved in mediating recombination of homologous chromosomes and DNA mismatch repair in the mouse [59]. These events occur during the meiotic prophase, the stage where oocytes are blocked for a long time before meiotic maturation.

\section{Conclusion}

In conclusion, the findings of the present study on spatiotemporal expression of 8 chicken oocyte specific genes (chkmos, btg4, wee, zpA, dazL, cvh, zar1 and ktfn) were consistent with our hypothesis that oocyte-specific genes in the chicken should play a major role in oocyte maturation, fertilization and early embryo development as in the mouse [12]. Other genes, whose mRNA expression were found in our study to be more specific for GCs or detected in both GCs and GDR depending on the stage, seem to be involved in follicular maturation (foxl2, transfac 20, mark $3, \ldots)$ and fertilization $(z p D$ and $z p C)$ rather than in early embryo development. Moreover, the microarray approach provided allowed the discovery of a set of new potential chicken mature oocyte and chicken granulosa cell markers for future studies. Interestingly, $40 \%$ of these genes had no homologs in the gene databases and some of them probably correspond to specific chicken mechanisms such as hierarchical follicular maturation or rapid yolk accumulation.

\section{Methods}

\section{Animals}

Laying breed hens aged 60-70 weeks (ISA Brown, egg layer type, Institut de Selection Animale, Saint Brieuc, France) were housed individually in laying batteries with free access to feed and water and were exposed to a 15L:9D photoperiod, with lights-on at $8.00 \mathrm{pm}$. Individual laying patterns were monitored daily. For in situ hybridization, these hens and younger ones of (10 weeks old) were used to provide mature and immature ovaries, in order to study follicles at each stage. Hens used to provide fertilized eggs were bred in the same conditions and inseminated once a week.

\section{Collection of tissues, oocytes and embryos}

Hens aged 60 weeks were used. Tissue samples were collected from the ovary, spleen, intestine, gizzard, liver, heart, skin, brain, pectoralis muscle, lung and pituitary gland. Germinal disc regions (GDR) and granulosa cells (GCs) surrounding the GDR (Fig. 1) were collected from different preovulatory follicles (F1 to F6), just ovulated oocytes and early embryos at $6.5 \mathrm{~h}, 12 \mathrm{~h}, 24 \mathrm{~h}, 36 \mathrm{~h}$ and $48 \mathrm{~h}$ post ovulation. The GDR and GCs surrounding the GDR were carefully dissected in the same way under a binocular microscope using fine forceps and scissors (World Precision Instruments) as previously described for quail oocytes [60]. After washing in phosphate buffer saline (PBS, Gibco, Cergy Pontoise, France) GDR and GCs were frozen in liquid nitrogen and then were stored at $-80^{\circ} \mathrm{C}$ until use. For the last two stages, eggs were incubated at $37.8^{\circ} \mathrm{C}$ for 12 and $24 \mathrm{~h}$, respectively. The $6.5 \mathrm{~h}, 12 \mathrm{~h}$, and $24 \mathrm{~h}$ stages of embryo development correspond to stages $\mathrm{I}, \mathrm{V}$ and $\mathrm{X}$ of the Eyal-Giladi and Kochav classification, respectively [61]. The $36 \mathrm{~h}$ and $48 \mathrm{~h}$ stages correspond to stages 3 and 6 of the Hamburger-Hamilton classification, respectively [62]. During follicular maturation the germinal disc is closely associated with its overlying granulosa cells (GCs) and forms a structure called the germinal disc region (GDR) (Figure 1). The GDR from F6-F1 follicles used for these studies consisted not only of the germinal disc but also of the overlying layer of GCs, because GD and overlying GCs cannot be completely separated $[60,63,64]$ and the number of GCs in GDR preparations could not be counted.

\section{Bioinformatic analysis}

A differential digital display analysis has already been performed with mouse ESTs [25-27], providing a list of murine oocyte-specific genes. Using this murine gene list, we systematically searched for chicken orthologs of these genes in international public databases pubmed [65]. Blast bit scores higher than 100 were retained. Moreover, the physical localization of genes identified on chicken chromosomes was retrieved from both mapview [28] and from blat search [29]. We also verified that chicken homologs were localized in the syntenic genomic regions conserved with that of mouse species to have a better chance that true orthologs were studied with ensembl [66].

\section{RNA isolation and Microarray Analysis}

Total RNA was extracted from GDR of F1 and ovulated oocytes, and from GCs of F1 follicles as described above. We thus had 3 samples with a biological replicate of each sample. The RNeasy Mini Kit (QIAGEN, Hilden, Germany) was used according to the manufacturer's instructions. The tissues (GDR or GC) from 25 hens were pooled for each stage investigated to obtain enough RNA for probe synthesis. Two such a pools were constituted for 
each sample in order to achieve two biological replicates of microarray hybridization. All RNA samples were checked for their integrity on the Agilent 2100 bioanalyzer according to Agilent Technologies guidelines (Waldbroon, Germany). Two micrograms of total RNA were reverse transcribed with the One-cycle cDNA synthesis kit (Affymetrix, Santa Clara, CA), according to the manufacturer's procedure. Clean up of the double-stranded cDNA was performed with Sample Cleanup Module (Affymetrix, Santa Clara, CA) followed by in vitro transcription (IVT) in the presence of biotin-labelled UTP using GeneChip ${ }^{\circledast}$ IVT labelling Kit (Affymetrix). The quantity of the cRNA labelled with RiboGreen ${ }^{\circledast}$ RNA Quantification Reagent (Turner Biosystems, Sunnyvale, CA) was determined after cleanup by the Sample Cleanup Module (Affymetrix). Fragmentation of $15 \mu \mathrm{g}$ of labelled-cRNA was carried out for 35 minutes at $94^{\circ} \mathrm{C}$, followed by hybridization for 16 hours at $45^{\circ} \mathrm{C}$ to Affymetrix GeneChip ${ }^{\oplus}$ Chicken Genome Array, representing approximately 32,773 transcripts, corresponding to over different 28,000 Gallus gallus genes. After hybridization, the arrays were washed with 2 different buffers (stringent: 6X SSPE, $0.01 \%$ Tween- 20 and nonstringent: $100 \mathrm{mM}$ MES, $0.1 \mathrm{M}[\mathrm{Na}+], 0.01 \%$ Tween-20) and stained with a complex solution including Streptavidin R-Phycoerythrin conjugate (Invitrogen/molecular probes, Carlsbad, CA) and anti Streptavidin biotinylated antibody (Vectors laboratories, Burlingame, CA). The washing and staining steps were performed in a GeneChip ${ }^{\circledast}$ Fluidics Station 450 (Affymetrix). The Affymetrix GeneChip ${ }^{\circledast}$ Chicken Genome Arrays were finally scanned with the GeneChip ${ }^{\circledast}$ Scanner $30007 \mathrm{G}$ piloted by the GeneChip ${ }^{\circledast}$ Operating Software (GCOS).

All these steps were performed on Affymetrix equipement at INRA-URGV, Evry, France.

The .raw CEL files were imported in R software for data analysis. All raw and normalized data are available from the Gene Expression Omnibus (GEO) repository at the National Center for Biotechnology Information (NCBI) [67], accession number GSE7805. Gene Ontology annotations were performed with NetAffx.

\section{RNA extraction and reverse transcription}

Total RNA was extracted from whole adult tissues (ovary, spleen, intestine, gizzard, liver, heart, skin, brain, pectoralis muscle, lung and pituitary gland) using Tri-reagent (Euromedex, Mundolsheim, France) according to the manufacturer's procedure. RNA quality and quantity were then assessed by using RNA nano chips and Agilent RNA 6000 nano reagents (Agilent Technologies, Waldbronn, Germany) according to the manufacturer's instructions. Samples were stored at $-80^{\circ} \mathrm{C}$ until use. Reverse transcription (RT) was performed to test the expression of candidate genes in different tissues and at different stages of follicular maturation and embryo development using polymerase chain reactions (PCR). One microgram of total RNA extracted from tissues or GDR was digested by RQ1 DNase (Promega, Madison, WI, USA) and reverse transcribed to first-strand cDNA using Moloney Murine Leukemia Virus reverse transcriptase I with an oligo dTrandom primer mix (Promega, Madison, WI, USA) according manufacturer's instructions.

Labelled RT was performed in order to assess mRNA quality in GDR of F1 stage and just ovulated oocytes. Ten $\mu \mathrm{Ci}$ $\alpha$ P32 dCTP was added to the reverse transcription mix in order to label cDNA. Labelled cDNA was then separated on $1.2 \%$ denaturing agarose gel $(50 \mathrm{mM} \mathrm{NAOH}, 1 \mathrm{mM}$ EDTA) by electrophoresis. A storage phosphor screen (Amersham Biosciences, Bucks, UK) was placed on the gel in an exposure cassette (Amersham Biosciences, Bucks, UK). The signal was detected one hour later with a STORM 840 (Molecular Dynamics), a phosphor screen imaging system.

\section{Real time RT-PCR}

Specific sets of primer pairs (Sigma Genosis), designed using Vecteur NTI software to amplify fragments of 21 different transcripts, are shown in Table 4. Real time PCR reactions were carried out in $25 \mu \mathrm{l}$ containing primers at a final concentration of $150 \mathrm{~nm}$ of each, $5 \mu \mathrm{l}$ of the RT reaction diluted 1/30 and qPCR Mastermix Plus for Sybr Green I (Eurogentec) according to the manufacturer's instructions. Real time PCR was performed using an ABI Prism 7000 (Applied Biosystems). After incubation at $50^{\circ} \mathrm{C}$ for $2 \mathrm{~min}$, and $95^{\circ} \mathrm{C}$ for $10 \mathrm{~min}$, the thermal cycling protocol was as follows: 40 cycles at $95^{\circ} \mathrm{C}$ for $15 \mathrm{sec}$ and $60^{\circ} \mathrm{C}$ for $1 \mathrm{~min}$. The amounts of $18 \mathrm{~S}$ rRNA and $28 \mathrm{~S}$ rRNA were measured in the RT reactions diluted 1/5000 using $28 \mathrm{~S}$ rRNA and $18 \mathrm{~S}$ rRNA control kits (Eurogentec), respectively, according to the manufacturer's instructions. PCR amplification without cDNA was performed systematically as a negative control. 18S rRNA was used as a reporter gene in the study of the mRNA tissular expression pattern, whereas $\beta$ actin,gapdh and ef1 $\alpha$ were used as reporter genes in the mRNA expression study during follicular maturation and early embryo development, the expression of these three genes being similar in GCs and in GDR (data not shown). In both cases (tissular expression study or temporal dynamic study) the samples were analyzed in duplicate on the same plate for a given gene. Real time RT-PCR was performed in the temporal dynamic study with two biological replicates of each sample. Melting curve analysis was systematically performed for all genes in order to verify the specificity of the PCR product. Real time PCR efficiency (E) was measured in duplicate on serial dilutions of cDNA (pool of reversetranscribed RNA from GDR and GC samples at the same stages as used for the temporal dynamic study) for each 
Table 4: Oligonucleotide primer sequences

\begin{tabular}{|c|c|c|c|c|c|}
\hline & Abbreviation & Forward & Reverse & Efficiency & Length (bp) \\
\hline \multirow[t]{24}{*}{ Real time PCR } & btg4 & TTGGGTGTTTTTGGGAGG & AGTGCTTCAACTGCTTCTCAGACC & 1.93 & 187 \\
\hline & chkmos & TACTCGTGTGACATCGTGACTGGC & TTGCTGGCAAACATGGTGGC & 2.09 & 177 \\
\hline & dazL & TACCCATTCGTCAACAACCTGC & CCСTTTGGAAACACCAGTTCTG & 1.88 & 184 \\
\hline & fbox & ACCTGTGCTGGATGATGTTGACC & CAACAAGAGGTATGTGCTTTGCG & 1.81 & 197 \\
\hline & hsfl & ACCCCTATTTCATCCGTGGC & AGTCCATGCTCTCCTGCTTTCC & 1.80 & 165 \\
\hline & msh4 & GATTCTCGGAATGGTCACACGC & AGCATCAACAAGTGGCTCCAGG & 2.16 & 105 \\
\hline & mtprd & TGAAGATCAAGGTCCAACAACTGC & TTGCTTCCTGAAACCTTTGGC & 1.80 & 180 \\
\hline & mcmip & CGTGATGGCAGGAGAAGAAAGC & $\begin{array}{c}\text { ATGAGTGAGGAAGGATGGGTGAC } \\
\text { C }\end{array}$ & 1.80 & 165 \\
\hline & zn finger RIZ & GAGCAAAAGAGTACATCAGAGG & CCATTTGATTCACCTCTTGC & 1.80 & 89 \\
\hline & mark3 & $\begin{array}{c}\text { AGTGAAAGAACCACTGCTGATAGG } \\
\text { C }\end{array}$ & TTGAAGCGACAGGCGTTCTTT & 1.83 & 91 \\
\hline & $\operatorname{discs} 5$ & $\begin{array}{c}\text { ATGACTGTATGGTGGTTGAGACTG } \\
\text { C }\end{array}$ & CGGCCTTTTGAAAGTATCAGGG & 1.81 & 176 \\
\hline & trans fact 20 & TCAAAACTCAGCACCAGCCC & GTGCAGGTTTCTCTTGTCCACC & 1.92 & 178 \\
\hline & wee & $\begin{array}{c}\text { GGAGAAGAGGGTGAAGACAGAAG } \\
\text { C }\end{array}$ & TGAGCTTCCTGTGAGGAGTTGC & 1.90 & $12 \mid$ \\
\hline & zarl & GTTTGTTTAGGGCTCTTCCAGGG & TTTACTCGCAGCTTTCCCAGC & 2.20 & 92 \\
\hline & ktfn & АСTATTTTTСTССTССTGССTCTGC & AATGCCAAATACAAGCGGGG & 2.05 & 186 \\
\hline & zpA & ССТTAАATCСАACAАCTCСACAGC & CAGCAAAAATCCCAACAAGAGG & 1.92 & $|3|$ \\
\hline & zpC & АCTAGCTCTGCCTTCATCACACCC & GGCAGGTGATGTAGATCAGGTTCC & 1.80 & 109 \\
\hline & foxL2 & Govoroun et al. 2004 & & 1.83 & \\
\hline & igf 2 & Heck et al. 2003 & & 1.85 & \\
\hline & $\mathrm{crh}$ & AGTTCCTGGCATCTTTGGGC & AGCGTCCTTTGAGAACTCCTGC & 2.00 & $13 \mid$ \\
\hline & zpD & TCATTGAGACAGGGAGGGAAGC & TCTTCACCACCTGCTCATAGGC & 1.90 & 102 \\
\hline & gapdh & TGCTGCCCAGAACATCATCC & ATCAGCAGCAGCCTTCACTACC & 2.05 & 199 \\
\hline & beta actin & CAGATGTGGATCAGCAAGCAGG & TTTCATCACAGGGGTGTGGG & 1.88 & 107 \\
\hline & efl alpha & AGC AGA CTT TGT GAC CTT GCC & TGA CAT GAG ACA GAC GGT TGC & 2.00 & 90 \\
\hline \multirow[t]{8}{*}{ in situ hybridization } & btg4 & ACGGTCTTCTTCATCACGAGGC & TCTGTAGCACCAGCCTTCATCC & & 729 \\
\hline & chkmos & CCCTGGCAAAGATGGAAAAGC & CAGAGGGTGATGGCAAAGGAGT & & 732 \\
\hline & dazL & TGTTTTTAAGTGTGCGGGCG & $\begin{array}{c}\text { ACTATTACCAGACATCTGTGTGGG } \\
\text { C }\end{array}$ & & 749 \\
\hline & fbox & TGTGTTCCTTTACCCCGATTGC & $\begin{array}{c}\text { AACTGCTACACTGCTTTCAGTCAG } \\
\text { G }\end{array}$ & & 794 \\
\hline & zpA & TCATCGCTCСTCTCTTTGTTGG & TTTGCATGTGGGATCTCTGAGC & & 773 \\
\hline & zpC & TACCGCACGCTCATCAACTACG & ATCAGCTGCAACCTCTTTCCCG & & 744 \\
\hline & $\mathrm{cvh}$ & AGTTCCTGGCATCTTTGGGC & ATATCGAGCATGCGGTCTGC & & 792 \\
\hline & zpD & TATTTGCTGCTGTTCTCTGCCC & TGGTGCTGCCCTTCTATCTTCA & & 740 \\
\hline
\end{tabular}

primer pair and was calculated using the following equation: $\mathrm{E}=\left(10^{1 / \text { slope }}\right)^{-1}$. In the tissular expression study the relative amounts of gene transcripts $(R)$ were calculated according to the equation:

$$
\mathrm{R}=\frac{\mathrm{E}_{\text {gene }}^{-\mathrm{Ct} \text { gene }}}{\mathrm{E}_{\text {18S rRNA }}^{-\mathrm{Ct} \text { 18S rRA }}}
$$

where $\mathrm{Ct}$ is a cycle threshold. In the temporal dynamic study R was calculated using following equation:

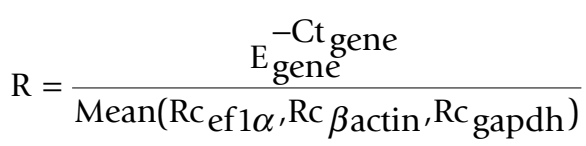

where Rc is corrected relative reporter gene expression calculated as explained below. In order to take into account only fold changes in the expression levels of reporter genes between samples but not the differences in the expression levels of reporter genes in the sample, the expression levels of reporter genes in each sample (sample $_{\mathrm{i}}$ ) was adjusted against the relative amount of ef $1 \alpha$ in the F1GDR sample according to the equation:

$$
\mathrm{Rc}_{\text {reporter }}=\mathrm{E}_{e f 1 \alpha}^{-\mathrm{Ct}_{e f 1 \alpha \text { in F1GDR }}} \times \mathrm{E}_{\text {reporter }}^{\Delta \mathrm{Ct}_{\text {reporter }}}
$$

where $\Delta \mathrm{Ct}_{\text {reporter }}=\mathrm{Ct}_{\text {reporter in F1GDR }}-\mathrm{Ct}_{\text {reporter in sample }}$.

\section{Hierarchical clustering}

The hierarchical classification of data obtained using real time RT-PCR was performed with the Cluster 3.0 program 
using unsupervised single linkage or supervised complete linkage clustering in order to classify biological samples or to group together genes with a similar expression pattern, respectively [68].

\section{In situ hybridization}

Female chickens were sacrificed at different stages of sexual development. Two types of tissue were used, i.e. mature ovaries, containing follicles of different sizes (50 $\mu \mathrm{m}-7 \mathrm{~mm}$ ) from 60-week-old hens (most follicles being larger than $300 \mu \mathrm{m}$ ) and immature ovaries, containing a majority of small follicles $(25-500 \mu \mathrm{m})$ from 10 -week-old hens (most follicles being smaller than $100 \mu \mathrm{m}$ ). Mature and immature ovaries were then collected and included in Tissue-Tek (Sakura Finetek Europe BV, Zoeterwoude, The Netherlands). Frozen ovaries were serially sectioned with a cryostat (thickness $10 \mu \mathrm{m}$ ) to perform in situ hybridization experiments using ${ }^{35} \mathrm{~S}$-labeled chicken gene cRNA. The gene antisense and sense constructs used for in situ hybridization were generated by inserting $700-800 \mathrm{bp}$ fragments of chicken gene cDNA into the pGEM-T vector (Promega, Madison, WI, USA), and selecting a clone with the appropriate antisense or sense orientation. The gene cDNA fragments were generated by RT-PCR from chicken ovary mRNA using forward and reverse primers (Table 4). The in situ hybridization was performed as previously described [69]. Hybridization specificity was assessed by comparing signals obtained with the cRNA antisense probe and the corresponding cRNA sense probe.

\section{Statistical analysis}

Data obtained after Affymetrix microarray hybridization analysis were normalized with the gcrma algorithm [70], available in the Bioconductor package [71]. Differential analysis was performed with the varmixt package of $\mathrm{R}$ [72]. A double-sided, unpaired $t$-test was computed for each gene between the two conditions. Variance of the difference in gene expression was split between subgroups of genes with homogeneous variance [72]. The raw $P$ values were adjusted by the Bonferroni method, which controls the Family Wise Error Rate (FWER) [73]. A gene is declared differentially expressed if the Bonferroni-corrected P-Value is less than 0.05 .

All other experimental data are presented as means \pm SEM. One-way analysis of variance (ANOVA) was used to test differences. If ANOVA revealed significant effects, the means were compared by Fisher's test, with $\mathrm{P}<0.05$ considered significant. Different letters indicate significant differences.

\section{Authors' contributions}

SE performed the experiences, the sequence alignment and the microarray analysis. FB participated in the design of the study and coordinated oocytes and embryos collec- tion. IC participated in the experiences. SB carried out the microarrays hybridization. MLMM performed the statistical analysis of microarray data. PM participated in the design of the study and provided the list of murine oocyte genes identified in silico. EB participated in the design of the study. MSG conceived of the study, and participated in its design and coordination. SE and MSG wrote and revised the manuscript. All authors read and approved the final manuscript.

\section{Additional material}

\section{Additional file 1}

Real time RT-PCR analysis of expression of chkmos, btg4, wee, zpA, dazL and cvh transcript during follicular maturation and early embryo development. The real time RT-PCR data provided represent the related expression of the 6 genes chkmos, btg 4 , wee, $\mathrm{zpA}$, dazL and cvh during follicular maturation and early embryo development, in granulos a cells and in germinal disc region.

Click here for file

[http://www.biomedcentral.com/content/supplementary/14712164-9-110-S1.png]

\section{Additional file 2}

Real time RT-PCR analysis of expression of $\mathrm{ktfn}, \mathrm{zar} 1, \mathrm{zpC}, \mathrm{zpD}$ and mcmip transcript during follicular maturation and early embryo development. The real time RT-PCR data provided represent the related expression of the 5 genes $\mathrm{ktfn}, \mathrm{zar} 1, \mathrm{zpC}, \mathrm{zpD}$ and mcmip during follicular maturation and early embryo development, in granulosa cells and in germinal disc region.

Click here for file

[http://www.biomedcentral.com/content/supplementary/1471-

2164-9-110-S2.png]

\section{Additional file 3}

Real time RT-PCR analysis of expression of mark3, igf2, trans fact 20, znfingerRIZ, msh4 and foxL2 during follicular maturation and early embryo development. The real time RT-PCR data provided represent the related expression of the 6 genes mark3, igf2, trans fact 20, znfinger$\mathrm{RIZ}, \mathrm{msh} 4$ and foxL2 during follicular maturation and early embryo development, in granulosa cells and in germinal disc region.

Click here for file

[http://www.biomedcentral.com/content/supplementary/1471-

2164-9-110-S3.png]

\section{Additional file 4}

Real time RT-PCR analysis of expression of discs $5, \mathrm{mtprd}$, fbox and hsf1 during follicular maturation and early embryo development. The real time $R T-P C R$ data provided represent the related expression of the 4 genes discs5, mtprd, fbox and hsf1 during follicular maturation and early embryo development, in granulosa cells and in germinal disc region. Related expression measured by real time RT-PCR (as described in materials and methods).

Click here for file

[http://www.biomedcentral.com/content/supplementary/14712164-9-110-S4.png] 


\section{Acknowledgements}

We thank Svétlana Uzbekova and Rozenn Dalbies-Tran for helpful discussion, Sonia Métayer for igf2 primers and Frederic Mercerand and JeanDidier Terlot-Bryssine for expert animal care. This study was supported by the "Institut National de la Recherche Agronomique". S Elis was supported by a fellowship from the Institut National de la Recherche Agronomique and "Région Centre".

\section{References}

I. Evsikov AV, Graber JH, Brockman JM, Hampl A, Holbrook AE, Singh P, Eppig J], Solter D, Knowles BB: Cracking the egg: molecular dynamics and evolutionary aspects of the transition from the fully grown oocyte to embryo. Genes Dev 2006, 20:27I 3-2727.

2. Evsikov AV, de Vries WN, Peaston AE, Radford EE, Fancher KS, Chen FH, Blake JA, Bult CJ, Latham KE, Solter D, Knowles BB: Systems biology of the 2-cell mouse embryo. Cytogenet Genome Res 2004, 105:240-250.

3. Hake LE, Richter JD: Translational regulation of maternal mRNA. Biochimica et Biophysica Acta (BBA) - Reviews on Cancer 1997, 1332:M3I-M38.

4. Bashirullah A, Cooperstock RL, Lipshitz HD: Spatial and temporal control of RNA stability. Proc Natl Acad Sci U S A 200I, 98:7025-7028.

5. DeRenzo C, Seydoux G: A clean start: degradation of maternal proteins at the oocyte-to-embryo transition. Trends Cell Biol 2004, 14:420-426.

6. Alizadeh Z, Kageyama S, Aoki F: Degradation of maternal mRNA in mouse embryos: selective degradation of specific mRNAs after fertilization. Mol Reprod Dev 2005, 72:28I-290.

7. Schupbach T, Wieschaus E: Female sterile mutations on the second chromosome of Drosophila melanogaster. I. Materna effect mutations. Genetics 1989, I 21:101-117.

8. Golden A, Sadler PL, Wallenfang MR, Schumacher JM, Hamill DR, Bates G, Bowerman B, Seydoux G, Shakes DC: Metaphase to anaphase (mat) transition-defective mutants in Caenorhabditis elegans. / Cell Biol 2000, 15 I: | 469-| 482.

9. Christians ES: [When the mother further impacts the destiny of her offspring: maternal effect mutations]. Med Sci (Paris) 2003, 19:459-464

10. Pelegri F, Knaut H, Maischein HM, Schulte-Merker S, Nusslein-Volhard C: A mutation in the zebrafish maternal-effect gene nebel affects furrow formation and vasa RNA localization. Curr Biol 1999, 9: | 431-1440.

II. Kubota HY, Itoh K, Asada-Kubota M: Cytological and biochemical analyses of the maternal-effect mutant embryos with abnormal cleavage furrow formation in Xenopus laevis. Dev Biol |99|, | 44:|45-I5I.

12. Dean J: Oocyte-specific genes regulate follicle formation, fertility and early mouse development. J Reprod Immunol 2002, 53:17|- 180

13. Zagris N, Kalantzis K, Guialis A: Activation of embryonic genome in chick. Zygote 1998, 6:227-231.

14. Meirelles FV, Caetano AR, Watanabe YF, Ripamonte P, Carambula SF, Merighe GK, Garcia SM: Genome activation and developmental block in bovine embryos. Animal Reproduction Science Research and Practice III I5th International Congress on Animal Reproduction 2004, 8283:13-20.

15. Eric M. Thompson EL Jean-Paul Renard,: Mouse embryos do not wait for the MBT: Chromatin and RNA polymerase remodeling in genome activation at the onset of development. Developmental Genetics 1998, 22:31-42.

16. Callebaut M: Origin, fate, and function of the components of the avian germ disc region and early blastoderm: role of ooplasmic determinants. Dev Dyn 2005, 233:| | 194-1216.

17. Yao HH, Bahr JM: Chicken granulosa cells show differential expression of epidermal growth factor (EGF) and luteinizing hormone (LH) receptor messenger RNA and differential responsiveness to EGF and LH dependent upon location of granulosa cells to the germinal disc. Biol Reprod 200I, 64:1790-1796.

18. Etches RJ, Petitte JN: Reptilian and avian follicular hierarchies: models for the study of ovarian development. J Exp Zool Suppl 1990, 4: II $12-122$
19. Olszanska B: [Role of polyadenylic segments and RNA polyadenylation in embryonic development]. Postepy Biochem 1985, 31:365-384.

20. Olszanska B, Borgul A: Quantitation of nanogram amounts of nucleic acids in the presence of proteins by the ethidium bromide staining technique. Acta Biochim Pol 1990, 37:59-63.

21. Olszanska B, Borgul A: Maternal RNA content in oocytes of several mammalian and avian species. J Exp Zool 1993, 265:317-320.

22. Olszanska B, Kludkiewicz B, Lassota Z: Transcription and polyadenylation processes during early development of quail embryo. J Embryol Exp Morphol 1984, 79: I I-24.

23. Tsunekawa N, Naito M, Sakai $Y$, Nishida T, Noce T: Isolation of chicken vasa homolog gene and tracing the origin of primordial germ cells. Development 2000, I 27:274|-2750.

24. Wang Y, Li J, Ying Wang C, Yan Kwok AH, Leung FC: Epidermal growth factor (EGF) receptor ligands in the chicken ovary: I. Evidence for heparin-binding EGF-like growth factor (HBEGF) as a potential oocyte-derived signal to control granulosa cell proliferation and HB-EGF and kit ligand expression. Endocrinology 2007, I 48:3426-3440.

25. Dade S, Callebaut I, Mermillod P, Monget P: Identification of a new expanding family of genes characterized by atypical LRR domains. Localization of a cluster preferentially expressed in oocyte. FEBS Lett 2003, 555:533-538.

26. Dade S, Callebaut I, Paillisson A, Bontoux M, Dalbies-Tran R, Monget $P$ : In silico identification and structural features of six new genes similar to MATER specifically expressed in the oocyte. Biochem Biophys Res Commun 2004, 324:547-553.

27. Paillisson A, Dade S, Callebaut I, Bontoux M, Dalbies-Tran R, Vaiman $D$, Monget $P$ : Identification, characterization and metagenome analysis of oocyte-specific genes organized in clusters in the mouse genome. BMC Genomics 2005, 6:76

28. Mapview [http://www.ncbi.nlm.nih.gov/projects/mapview/]

29. blat search [http://www.genome.ucsc.edu/cgi-bin/hgBlat]

30. Elis S, Dupont J, Couty I, Persani L, Govoroun M, Blesbois E, Batellier F, Monget P: Expression and biological effects of bone morphogenetic protein-15 in the hen ovary. J Endocrinol 2007, 194:485-497.

3I. Okumura H, Kohno Y, Iwata Y, Mori H, Aoki N, Sato C, Kitajima K, Nadano D, Matsuda T: A newly identified zona pellucida glycoprotein, ZPD, and dimeric ZPI of chicken egg envelope are involved in sperm activation on sperm-egg interaction. Biochem J 2004, 384:191-199.

32. Goudet G, Mugnier S, Callebaut I, Monget P: Phylogenetic Analysis and Identification of Pseudogenes Reveal a Progressive Loss of Zona Pellucida Genes During Evolution of Vertebrates. Biol Reprod 2007.

33. Marina S Govoroun MP Eric Pailhoux, Julie Cocquet, Jean-Pierre Brillard, Isabelle Couty, Florence Batellier, Corinne Cotinot,: Isolation of chicken homolog of the FOXL2 gene and comparison of its expression patterns with those of aromatase during ovarian development. Developmental Dynamics 2004, 23 1:859-870.

34. Aegerter S, Jalabert B, Bobe J: Large scale real-time PCR analysis of mRNA abundance in rainbow trout eggs in relationship with egg quality and post-ovulatory ageing. Mol Reprod Dev 2005, 72:377-385

35. Heck A, Metayer S, Onagbesan OM, Williams J: mRNA expression of components of the IGF system and of $\mathrm{GH}$ and insulin receptors in ovaries of broiler breeder hens fed ad libitum or restricted from 4 to 16 weeks of age. Domest Anim Endocrinol 2003, 25:287-294.

36. Anckar J, Sistonen L: Heat shock factor I as a coordinator of stress and developmental pathways. Adv Exp Med Biol 2007, 594:78-88.

37. Okumura H, Aoki N, Sato C, Nadano D, Matsuda T: Heterocomplex Formation and Cell-Surface Accumulation of Hen's Serum Zona Pellucida B I (ZPB I)with ZPC Expressed by a Mammalian Cell Line (COS-7): A Possible Initiating Step of Egg-Envelope Matrix Construction. Biol Reprod 2007, 76:9-18.

38. Schmidt M, Oskarsson MK, Dunn JK, Blair DG, Hughes S, Propst F, Vande Woude GF: Chicken homolog of the mos proto-oncogene. Mol Cell Biol 1988, 8:923-929.

39. Maddox-Hyttel P, Svarcova O, Laurincik J: Ribosomal RNA and nucleolar proteins from the oocyte are to some degree used 
for embryonic nucleolar formation in cattle and pig. Theriogenology 2007, 68 Suppl I:S63-70.

40. De La Fuente R, Viveiros MM, Burns KH, Adashi EY, Matzuk MM, Eppig J]: Major chromatin remodeling in the germinal vesicle (GV) of mammalian oocytes is dispensable for global transcriptional silencing but required for centromeric heterochromatin function. Dev Biol 2004, 275:447-458.

41. Haccard O, Jessus C: Oocyte maturation, Mos and cyclins--a matter of synthesis: two functionally redundant ways to induce meiotic maturation. Cell Cycle 2006, 5: I I52-II59.

42. Inoue $D$, Ohe M, Kanemori $Y$, Nobui T, Sagata N: A direct link of the Mos-MAPK pathway to Erpl/Emi2 in meiotic arrest of Xenopus laevis eggs. Nature 2007, 446: I I00-1 I 04.

43. Yue J, Ferrell JE Jr: Mechanistic Studies of the Mitotic Activation of Mos. Mol Cell Biol 2006, 26:5300-5309.

44. Buanne P, Corrente G, Micheli L, Palena A, Lavia P, Spadafora C, Lakshmana MK, Rinaldi A, Banfi S, Quarto M, Bulfone A, Tirone F: Cloning of PC3B, a novel member of the PC3/BTG/TOB family of growth inhibitory genes, highly expressed in the olfactory epithelium. Genomics 2000, 68:253-263.

45. Pennetier S, Uzbekova S, Guyader-Joly C, Humblot P, Mermillod P, Dalbies-Tran R: Genes Preferentially Expressed in Bovine Oocytes Revealed by Subtractive and Suppressive Hybridization. Biol Reprod 2005, 73:713-720.

46. Vallee M, Gravel C, Palin MF, Reghenas H, Stothard P, Wishart DS, Sirard MA: Identification of Novel and Known Oocyte-Specific Genes Using Complementary DNA Subtraction and Microarray Analysis in Three Different Species. Biol Reprod 2005, 73:63-7I.

47. Aizawa K, Shimada A, Naruse K, Mitani H, Shima A: The medaka midblastula transition as revealed by the expression of the paternal genome. Gene Expr Patterns 2003, 3:43-47.

48. Xu H, Li M, Gui J, Hong Y: Cloning and expression of medaka dazl during embryogenesis and gametogenesis. Gene Expression Patterns 2007, 7:332-338.

49. Wassarman PM, Jovine L, Litscher ES: Mouse zona pellucida genes and glycoproteins. Cytogenet Genome Res 2004, 105:228-234.

50. Zeng F, Schultz RM: Gene expression in mouse oocytes and preimplantation embryos: use of suppression subtractive hybridization to identify oocyte- and embryo-specific genes. Biol Reprod 2003, 68:31-39.

51. Epifano O, Liang LF, Familari M, Moos MC Jr., Dean J: Coordinate expression of the three zona pellucida genes during mouse oogenesis. Development 1995, I 21 :1947-1956.

52. Takeuchi Y, Nishimura K, Aoki N, Adachi T, Sato C, Kitajima K, Matsuda T: A 42-kDa glycoprotein from chicken egg-envelope, an avian homolog of the ZPC family glycoproteins in mammalian zona pellucida. Its first identification, cDNA cloning and granulosa cell-specific expression doi:10.1046/j.14321327.1999.00203.x. European Journal of Biochemistry 1999, 260:736-742.

53. Kolle S, Dubois CS, Caillaud M, Lahuec C, Sinowatz F, Goudet G: Equine zona protein synthesis and ZP structure during folliculogenesis, oocyte maturation, and embryogenesis. Mol Reprod Dev 2007, 74:85I-859.

54. Wu X, Viveiros MM, Eppig J, Bai Y, Fitzpatrick SL, Matzuk MM Zygote arrest I (ZarI) is a novel maternal-effect gene critical for the oocyte-to-embryo transition. Nat Genet 2003, 33:|87-|9|.

55. Uzbekova S, Roy-Sabau M, Dalbies-Tran R, Perreau C, Papillier P, Mompart F, Thelie A, Pennetier S, Cognie J, Cadoret V, Royere D, Monget $P$, Mermillod $P$ : Zygote arrest I gene in pig, cattle and human: evidence of different transcript variants in male and female germ cells. Reprod Biol Endocrinol 2006, 4: I2

56. Cox DN, Lu B, Sun TQ, Williams LT, Jan YN: Drosophila par-I is required for oocyte differentiation and microtubule organization. Curr Biol 200I, I I:75-87.

57. Ossipova $\mathrm{O}, \mathrm{He} X, \mathrm{Green} \mathrm{J:} \mathrm{Molecular} \mathrm{cloning} \mathrm{and} \mathrm{developmen-}$ tal expression of Par-I/MARK homologues XPar-IA and XPar-IB from Xenopus laevis. Mech Dev 2002, II 9 Suppl I:SI 43-8.

58. Ossipova O, Dhawan S, Sokol S, Green JB: Distinct PAR-I proteins function in different branches of Wnt signaling during vertebrate development. Dev Cell 2005, 8:829-84I.
59. Acevedo N, Smith GD: Oocyte-specific gene signaling and its regulation of mammalian reproductive potential. Front Biosci 2005, 10:2335-2345.

60. Malewska A, Olszanska B: Accumulation and localisation of maternal RNA in oocytes of Japanese quail. Zygote 1999, 7:5I-59.

6I. Eyal-Giladi H, Kochav S: From cleavage to primitive streak formation: a complementary normal table and a new look at the first stages of the development of the chick. I. General morphology. Dev Biol 1976, 49:32I-337.

62. Hamburger V, Hamilton HL: A series of normal stages in the development of the chick embryo. 195I. Dev Dyn 1992, 195:23|-272.

63. Perry MM, Gilbert $A B$, Evans $A J$ : The structure of the germinal disc region of the hen's ovarian follicle during the rapid growth phase. J Anat 1978, 127:379-392.

64. Tischkau SA, Bahr JM: Avian germinal disc region secretes factors that stimulate proliferation and inhibit progesterone production by granulosa cells. Biol Reprod 1996, 54:865-870.

65. pubmed [http://www.ncbi.nlm.nih.gov/BLAST/Blast.cgi]

66. ensembl [http://www.ensembl.org/Gallus gallus/syntenyview]

67. Wheeler DL, Barrett T, Benson DA, Bryant SH, Canese K, Chetvernin V, Church DM, DiCuccio M, Edgar R, Federhen S, Geer LY, Helmberg W, Kapustin Y, Kenton DL, Khovayko O, Lipman DJ, Madden TL, Maglott DR, Ostell J, Pruitt KD, Schuler GD, Schriml LM, Sequeira E, Sherry ST, Sirotkin K, Souvorov A, Starchenko G, Suzek TO, Tatusov R, Tatusova TA, Wagner L, Yaschenko E: Database resources of the National Center for Biotechnology Information. Nucleic Acids Res 2006, 34:DI73-80.

68. Eisen MB, Spellman PT, Brown PO, Botstein D: Cluster analysis and display of genome-wide expression patterns. Proc Nat Acad Sci U S A 1998, 95: | 4863-|4868.

69. Pierre A, Pisselet C, Dupont J, Bontoux M, Monget P: Bone morphogenetic protein 5 expression in the rat ovary: biological effects on granulosa cell proliferation and steroidogenesis. Biol Reprod 2005, 73: I 102-1108.

70. Irizarry RA, Hobbs B, Collin F, Beazer-Barclay YD, Antonellis KJ, Scherf U, Speed TP: Exploration, normalization, and summaries of high density oligonucleotide array probe level data. Biostatistics 2003, 4:249-264.

71. Gentleman R, Carey V: Bioconductor. RNews 2002, 2:1।16.

72. Delmar P, Robin S, Daudin J]: VarMixt: efficient variance modelling for the differential analysis of replicated gene expression data. Bioinformatics 2005, 21:502-508.

73. Ge $Y$, Dudoit $S$, Speed TP: Resampling-based multiple testing for microarray data analysis. TEST 12 2003: I-44.
Publish with BiolMed Central and every scientist can read your work free of charge

"BioMed Central will be the most significant development for disseminating the results of biomedical research in our lifetime. "

Sir Paul Nurse, Cancer Research UK

Your research papers will be:

- available free of charge to the entire biomedical community

- peer reviewed and published immediately upon acceptance

- cited in PubMed and archived on PubMed Central

- yours - you keep the copyright 